\title{
Research Paper \\ Validity and Reliability of Persian Version of Onyx Social Capital Scale in Elderly People
}

\author{
Reza Eftekharian ${ }^{1}$, Alireza Kaldi ${ }^{1}$ *Shima Sum ${ }^{2}$, Robab Sahaf ${ }^{1}$, Reza Fadaei Vatan ${ }^{1}$
}

1. Iranian Research Center on Ageing, University of Social Welfare and Rehabilitation Sciences, Tehran, Iran. 2. Department of Social Medicine, School of Medicine, Babol University of Medical Sciences, Babol, Iran.

citation: Eftekharin R, Kaldi AR, Sam Sh, Sahaf R, Fadaei Vatan R. [Validity and reliability of Persian version of Onyx Social Capital Scale in elderly people (Persian)]. Iranian Journal of Ageing. 2016; 11(4):174-189. http://dx.doi.org/10.21859/sija-1101174

: http://dx.doi.org/10.21859/sija-1101174

Received: 04 Nov. 2015 Accepted: 12 Jan. 2016

Key words: Ageing, Social capital, Validity, Reliability, Social health

\section{A B STRACT}

Objectives Establishing social relationships and creating and reinforcing social networks among the elderly people may create social capital. Thus, this research aimed to translate Onyx and Bullen social capital questionnaire into Persian version and evaluate its validity and reliability for elderly people.

Methods \& Materials This cross-sectional study was conducted among 192 elderly people over 60 years old. To translate social capital instrument from English into Persian, we used the international quality of life assessment approach. Criterion validity of the instrument was using Geriatric Depression Scale (5 items), social health, and general health questionnaires. The obtained data were statistically analyzed.

Results According to our findings with regard to quality of the translation (clarity of translation, common language use, and conceptual equivalence, as well as general quality of translation), translators 3 and 4 found most items had clarity of translation (86.6\%), usage of common perception (76.3\%), conceptual consistency (76.3\%), and overall quality of translation (78.9\%). In other words, all were at a satisfactory level. The results showed that from experts' points of view, the Persian version of the questionnaire was good with regard to translation quality and acceptable at other aspects. In other words, it was not unacceptable with regard to any aspect. Interclass correlations (ICC) of the dimensions were more than 0.7. The Cronbach coefficient $\alpha$ was calculated as 0.96 for the overall scale. Factor analysis of this study among Iranian elderly found 7 factors, which had discreet differences with Onyx configuration. Thus, the questions related to neighborhood relations were put in the same factor with social cooperation, and some items related to social efficiency were put in the factor of social cooperation and some in the factor of trust feeling. These 7 factors all together explained $48.71 \%$ of the variance (KMO=0.835). The distribution of the variance of scores for 7 factors was as follows: social cooperation, 58.11\%; trust feeling, 48.8\%; life worthwhile, 44.8\%; work relations, 83,6\%; accepting differences, $79.6 \%$; family relationships, $58.6 \%$; and local solidarity, $83.6 \%$. Our findings also showed a negative and significant relationship between depression level and social capital $(\mathrm{P}=0.001)$. There was also a positive and significant association between social and general health level with social capital $(P=0.001)$.

Conclusion The Persian version of the questionnaire for this population has acceptable levels of face validity based on clarity, simplicity, and understandability of the questions, answers, and explanations of the Persian version of the social capital questionnaire. Therefore, this instrument is suitable for evaluating the level of social capital among the Iranian elderly people.

* Corresponding Author:

Shima Sum, PhD

Address: Department of Social Medicine, School of Medicine, Babol University of Medical Sciences, Babol, Iran.

Tel: +89 (113) 3192033

E-mail: sumshima@yahoo.com 


\title{
روايى يايايى نسخه فارسى يرسشنامه سرمايه اجتماعى اونيكس در سالمندان
}

\author{
رضا افتخاريان'، عليرضا كلدى'، "شيما سامّ، رباب صحاف'، رضا فدايعوطن' \\ ا- مركز تحقيقات سالمندى ايران، انشكاه علوم برزيستى و توانبخشى، تهران، ايران.

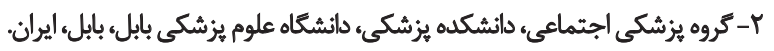

\begin{abstract}
حكبن

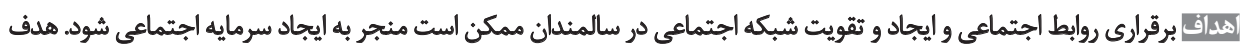

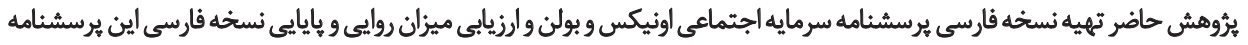
در بسالمندان بود.

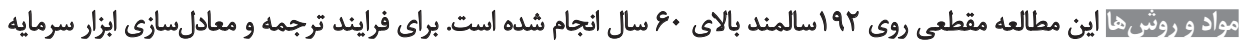

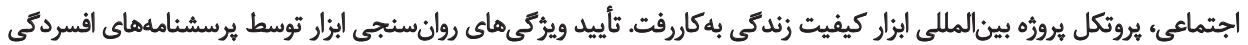

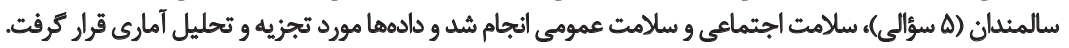

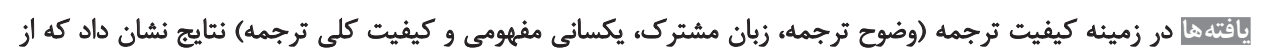

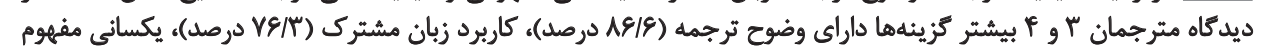

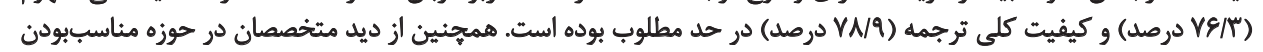

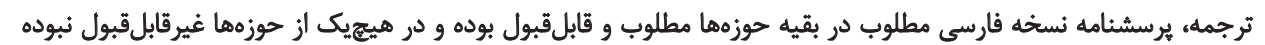

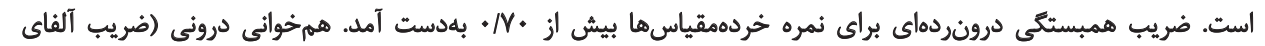

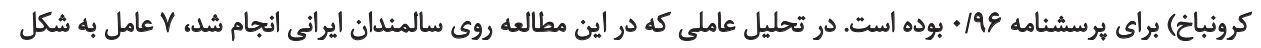

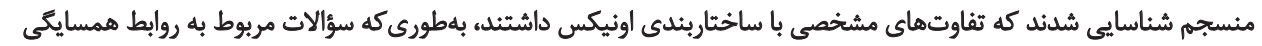

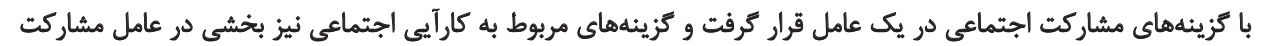

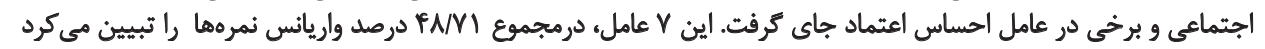
(KMO=•/ArA)

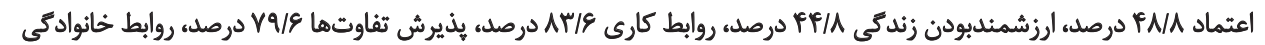

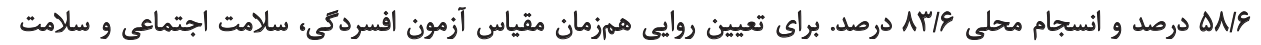

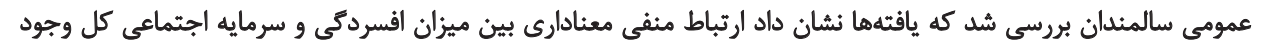

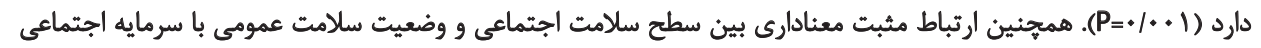

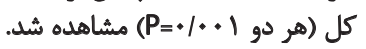

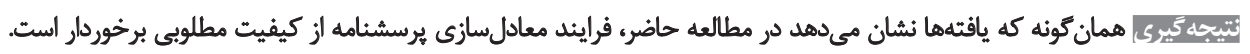

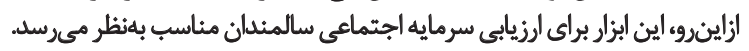

تاريخ دريافت: سו آبان

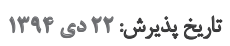

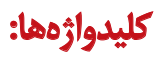

سالمندى، سرمايه اجتماعي،

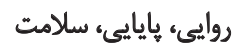
اجتماعي، افتسردكي، سلامت سلامت عمومى

بلويروه با اعضاى خانواده و همسايهها بهشكل قابلملاحظهاى بر

date

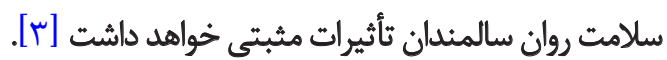

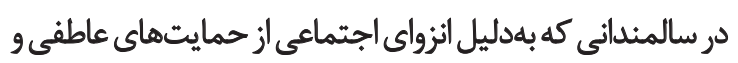

با تغييرات همهجانبهاي كه در ساختار اجتماعى جوامع در

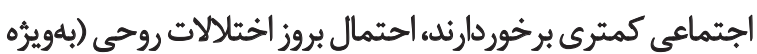

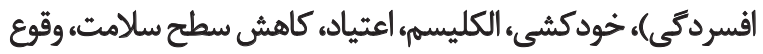

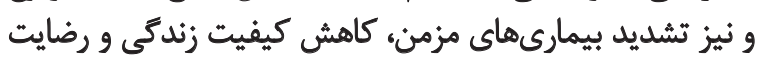

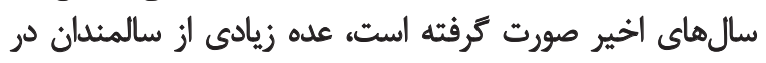

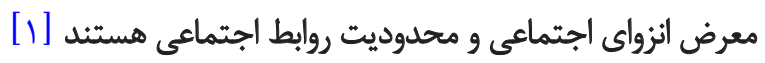

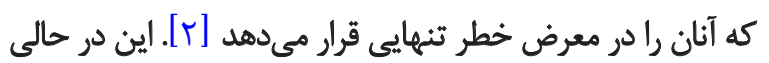

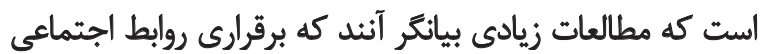

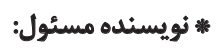

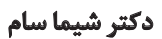

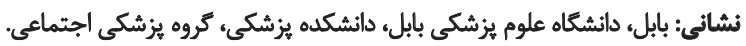

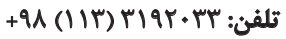
يست الكترونيكى: sumshima@yahoo.com 


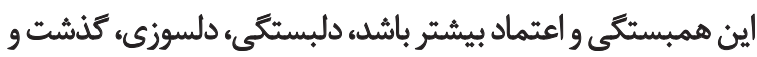

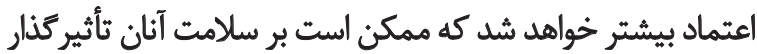

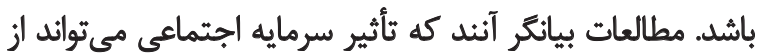

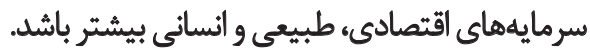
سرمايه اجتماعى يكى از اشكال سرمايه (بهجز سرمايه اقتصادى و

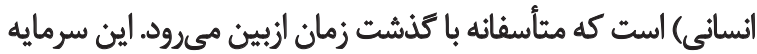

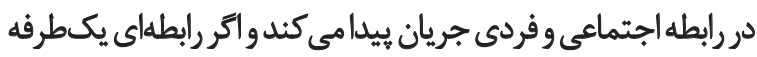

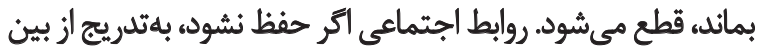

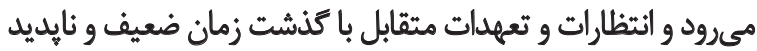

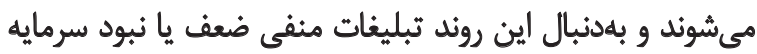

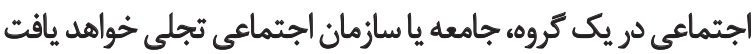

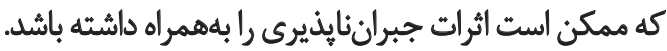
سرمايه اجتماعى مسئلهاى جِندبُعلى است كه ابعاد مختلفى

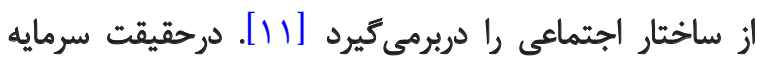
اجتماعى شىء واحدى نيست، بلكه مشتمل بر موارد كوناكونى

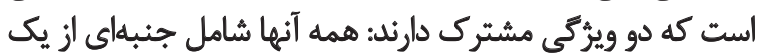

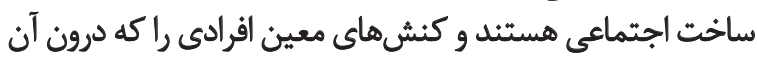

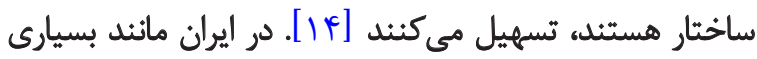

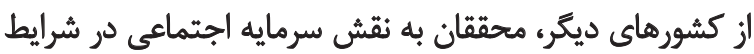

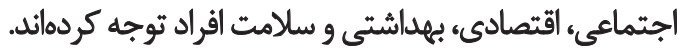
در صورت وجود ارتباط مثبت بين اين اجزا در سياستهايى كه

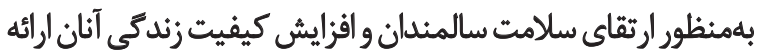

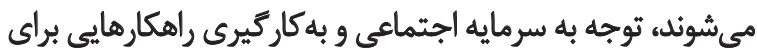

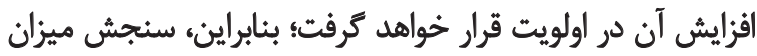

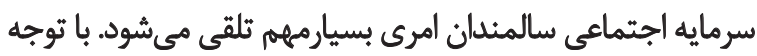

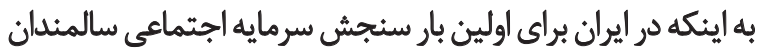

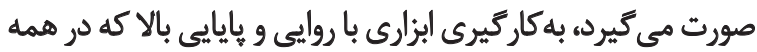

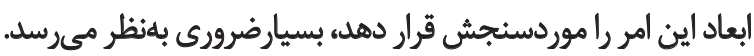
توافق كسترداي بر نحوه اندازهيرى سرمايه اجتماعي وجود

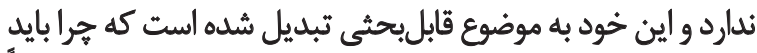

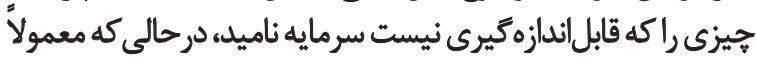

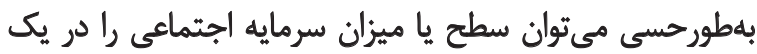

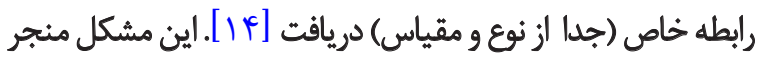

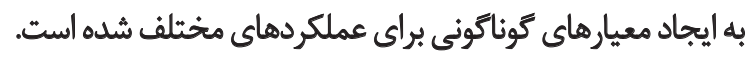

جامعهشناساني مانثل بنكستون و مينرو معتقدند يكي از دلايل

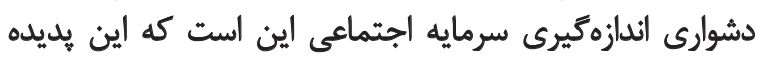

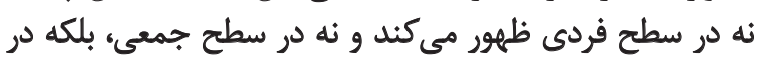

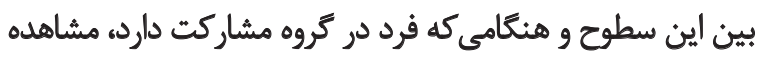

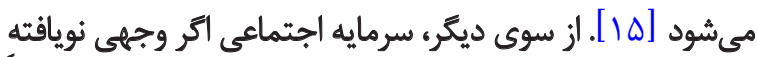

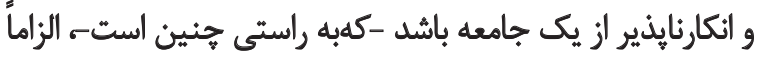

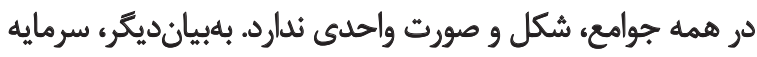

از آنه، افزّايش سطح ناتوانى و معلوليت و در انتهها، بسترىشدن

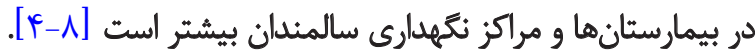

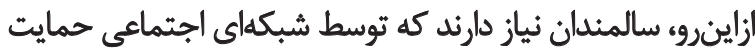

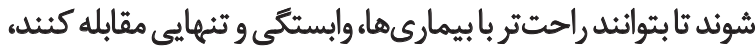

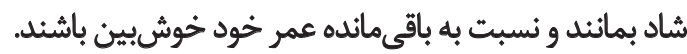

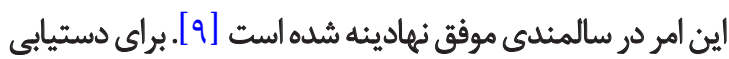

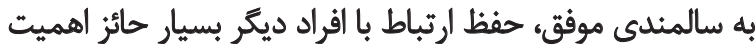

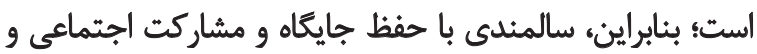

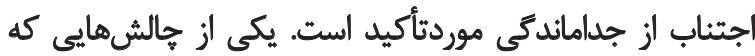

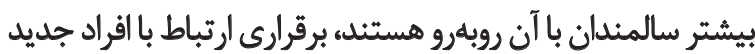

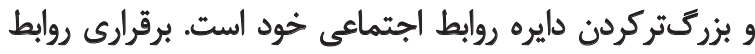

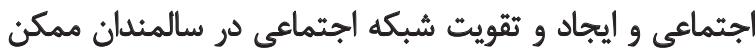
است منجر به ايجاد سرمايه اجتماعى شود [ •1]. بلنظر جامعهشئاسان در ابتداى تشكيل هر نظام اجتماعى، ثأثير

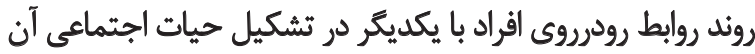

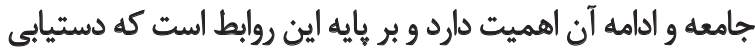

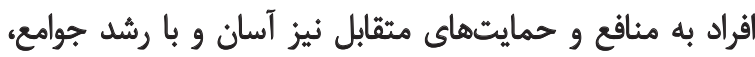

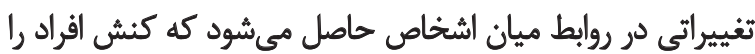

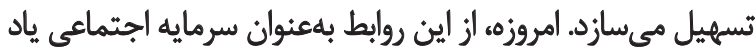
مي كنيند

با وجود تعاريف مختلف سرمايه اجتماعى، تاكنون تعريف منسجمى كه از تمامى ابعاد كوياى اين والره باشد، ارائه نشديه

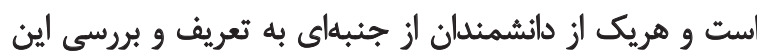

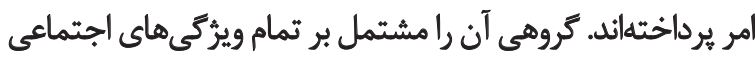

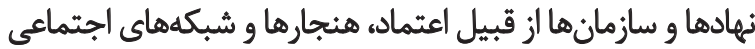

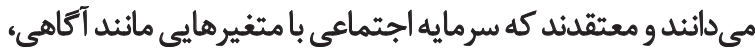

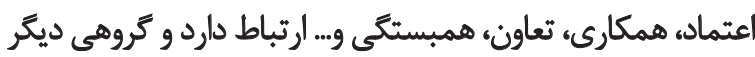

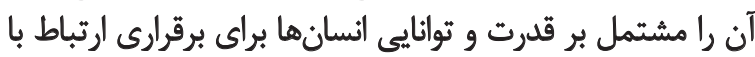
يكديكر تعريف كردهاند [11]

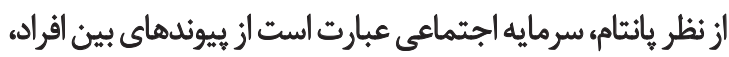

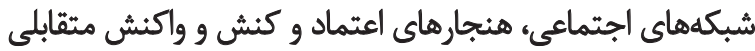

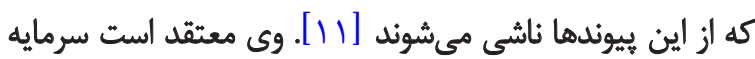

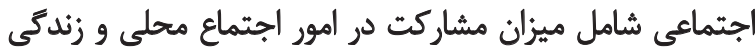

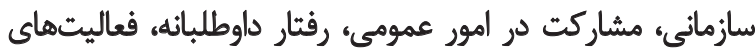

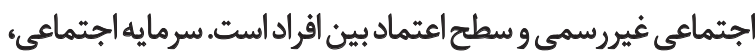

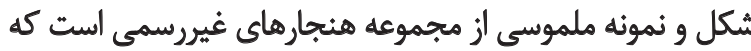

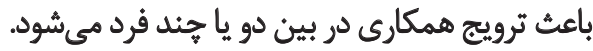
هنجارهاي تشكيل دهنده سرمايه اجتماعى هي توانند از هنجار

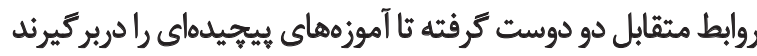

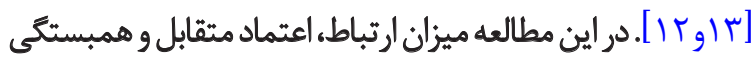
سالمندان به يكديكر و اعضاى ديكر جامعه موردثأكيد است. هرجيه 
معادل سازى فرهنكّى آن، روايى و هايايى آن را تأييد كرداند. اهداف كلى اين يرؤهش عبارت بودند ازئ بازنويسى يرسشنامه

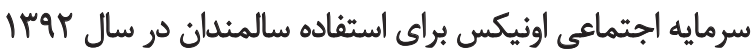

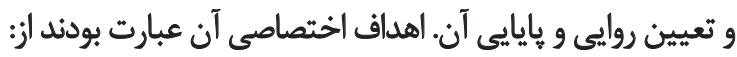
• تعيين دشوارى ترجمه نسخه فارسى ثرسشنامه سرمايه

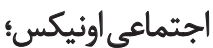

• تعيين كيفيت ترجمه نسخه فارسى شامل وضوح ترجمها، زبان مشترك، يكسانى مفهومى و كيفيت كلى ترجمها؛ •تعيين خُردممقياس هاى سرمايه اجتماعى اونيكس؛ •تعيين روايى ظاهرى و افتراقي آيتمهاي نسخه فارسى؛ • تعيين هايايى در دفعات آزمون نسخه فارسى؛ •تعيين همخوانى درونى نمرات نسخه فارسى؛ • تعيين روايى همزمان سرمايه اجتماعى با ابزارهاى افسردكىي،

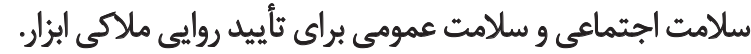

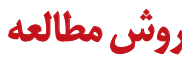

بُروهش حاضر، به روش مقطعى توصيفى-تحليلى انجام كرفت

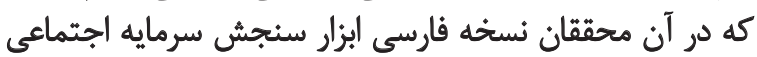

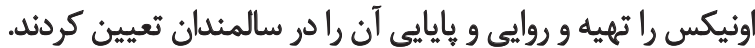

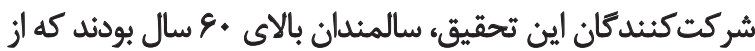

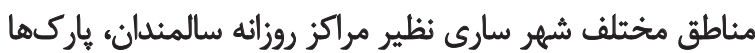

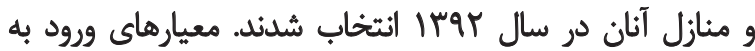

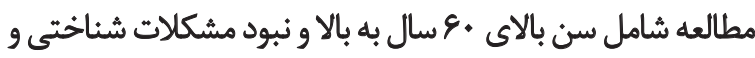

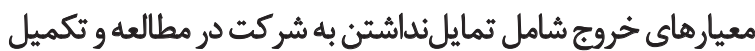
ناقص يرسشنامه بودند.

حجم نمونهها با توجه به فرمول تعيين حجم نمونه ضريب

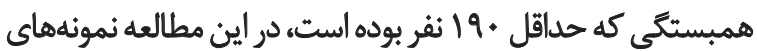

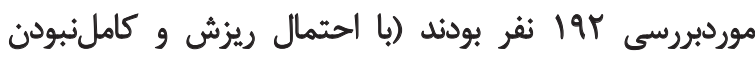

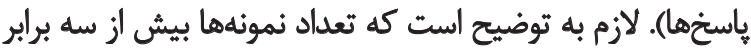

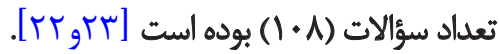

نمونهكيرى به روش غيراحتمالى (دردسترس) انجام كرفت كه

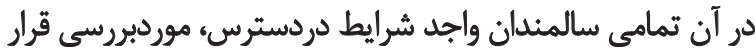

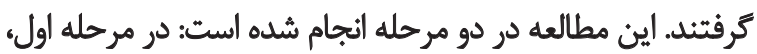

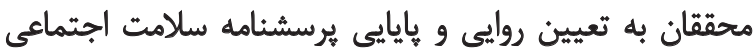

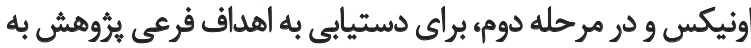

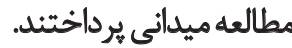

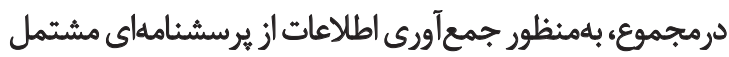

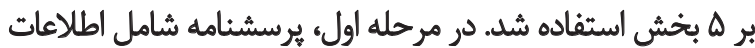

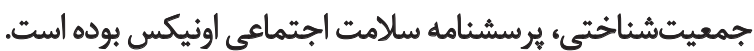

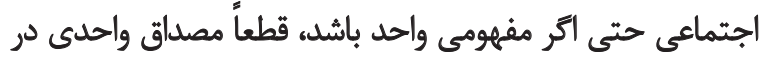

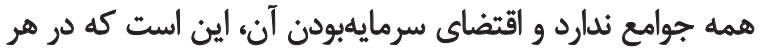
جامعاى متناسب با مقتضيات آن جامعه شكل مى تئيرد. براى اندازمكيرى سرمايه اجتماعي، ابزارهاى متفاوتى بهكار إفتئه

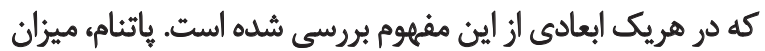

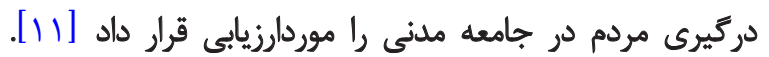

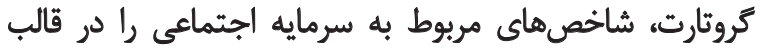

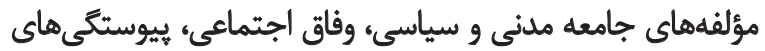

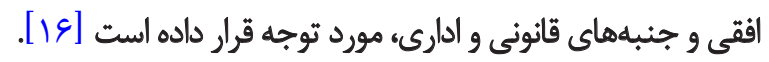
فوكوياما معتقد است سنجش سرمايه اجتماعى به دليل بُعد إند

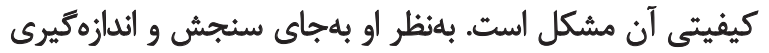

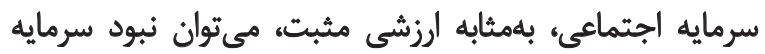

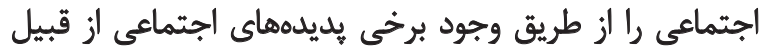

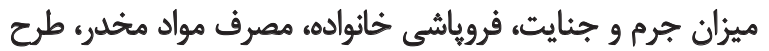
دعاوى و شكايت، خودكشى، فرار از ماليات و وبا روشهان فران مرسوم

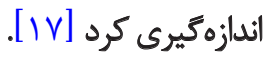

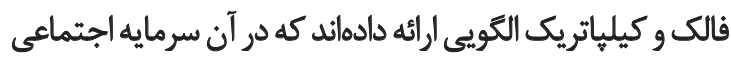

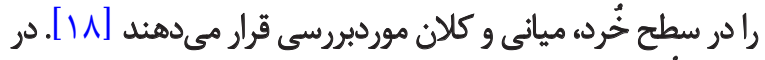

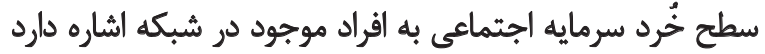

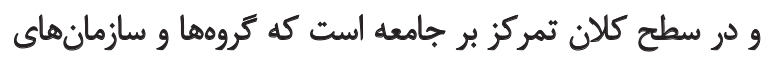

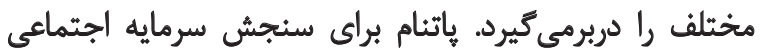

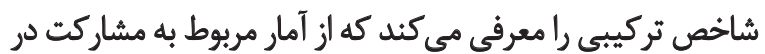

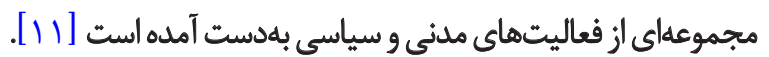

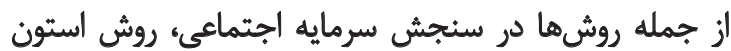

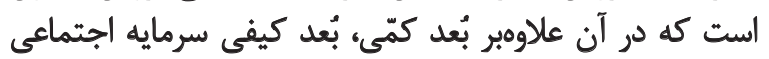

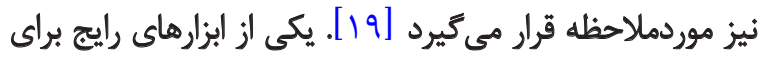

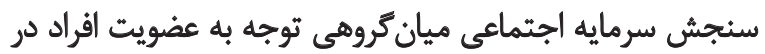

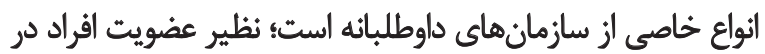

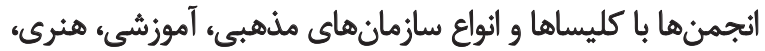

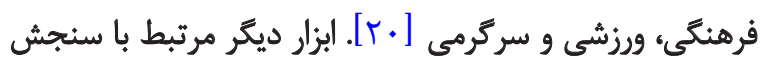
سرمايه اجتماعى كه در ه منطقه نيوساتولز استراليا استفاده شده،

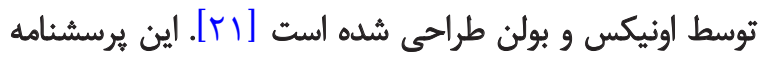

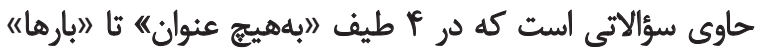
ميزان سرمايه اجتماعى افراد را موردبررسي قرار مي دهدي.

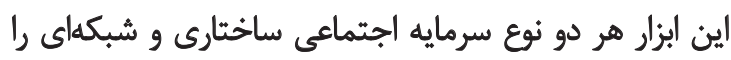

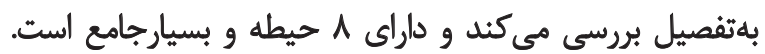

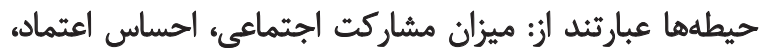

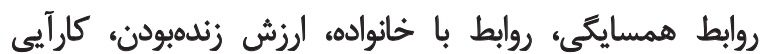

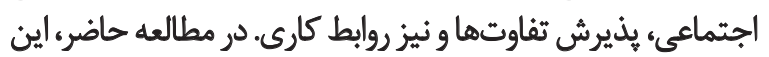

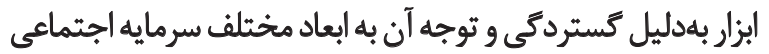

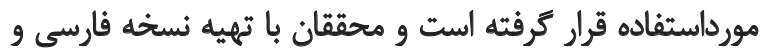




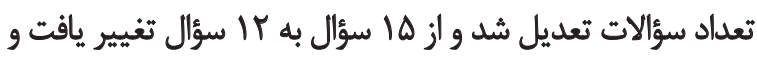

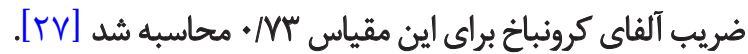

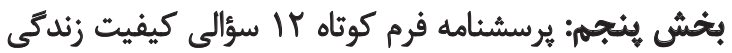

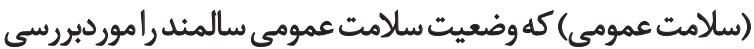

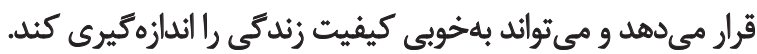

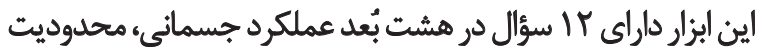

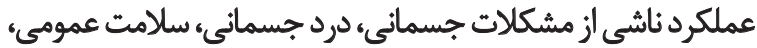

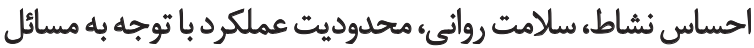
عاطفى و عملكرد اجتماعى است.

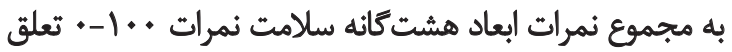

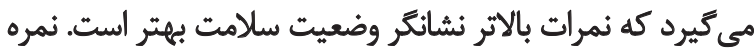

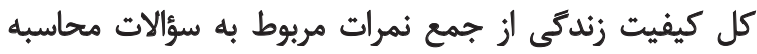

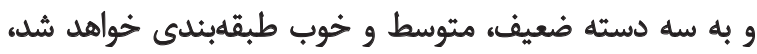

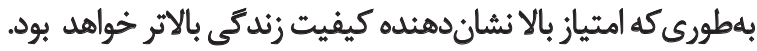

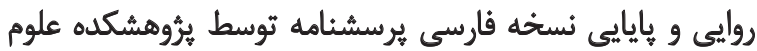

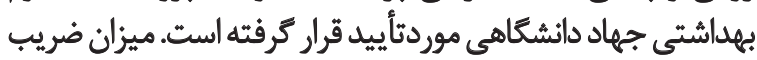

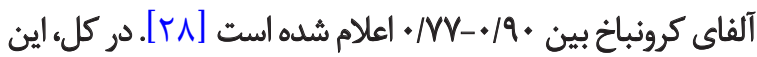

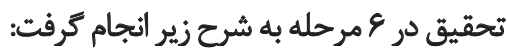
مرحله اول: ترجمه فارسى يرسشنامه ترجمه ابزار در ب مرحله صورت كرفت:

1 - ترجمه نسخه انكليسى به فارسى: در اين مرحله نسخه اصلى

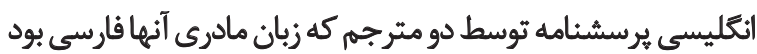

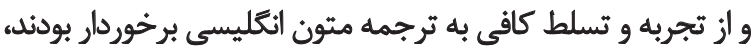

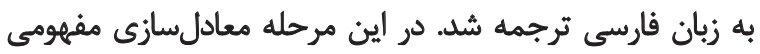

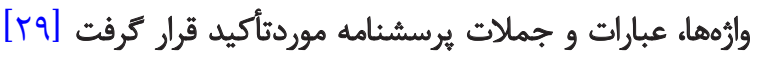

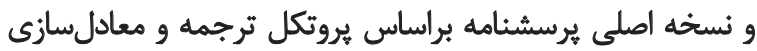

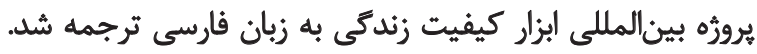

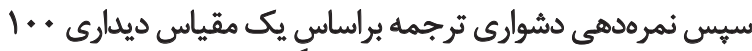

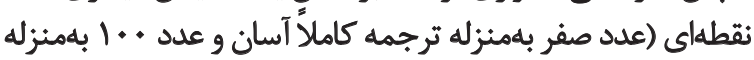

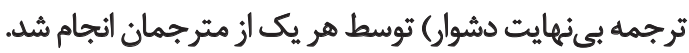
يس إزآن طى جلسهاي با حضور مترجمان، دانشجو و استاد راهنما

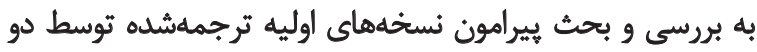

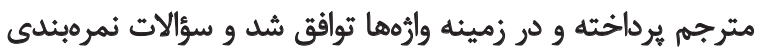

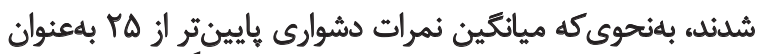

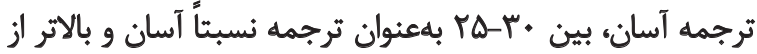

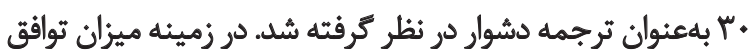

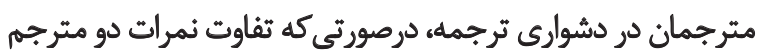

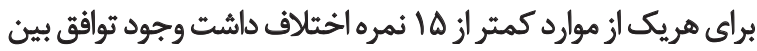

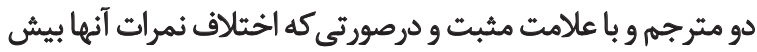

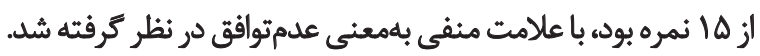

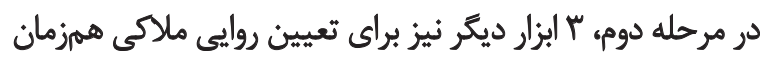

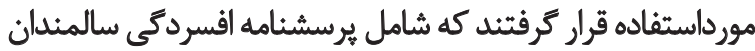

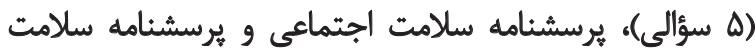

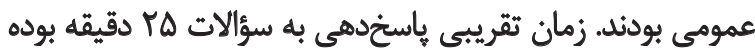
است. يرسشنامهها به تفكيك شامل خصوصيات زير بودند: بخش اول: دربركيرنده اطلاعات جمعيثشناختى افراد مانند

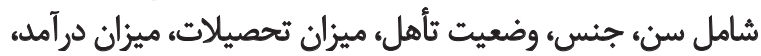

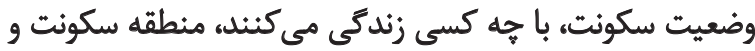
عضويت در انجمنها بود.

بخش دوم: ابزار مرتبط با سنجش سرمايه اجتماعى بود كه داراي

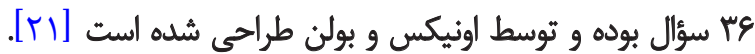

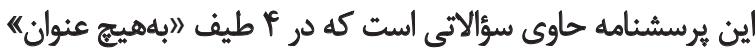

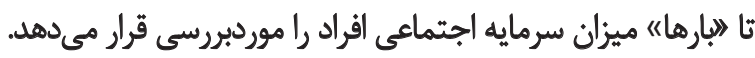

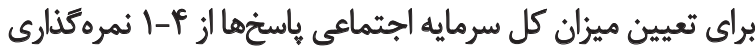

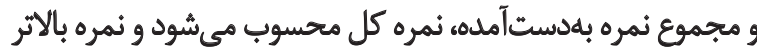

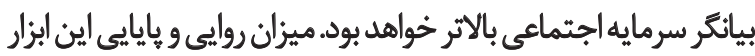

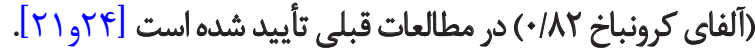

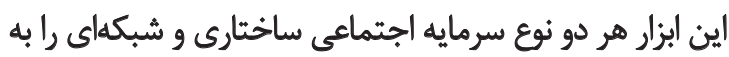

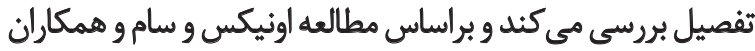

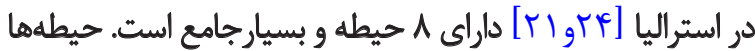

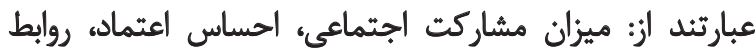

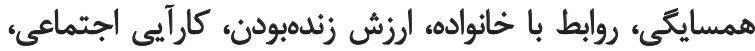

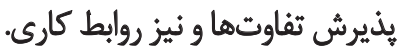

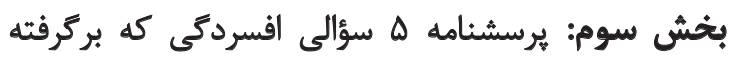

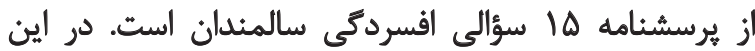

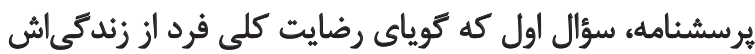

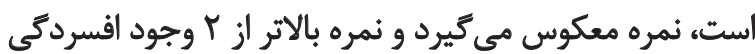

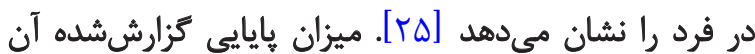

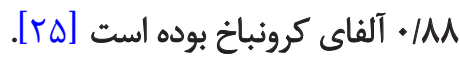

بخش هجهارم: در اين بخش از يرسشنامه تعيين سلامت

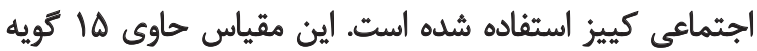

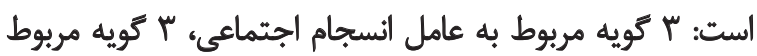

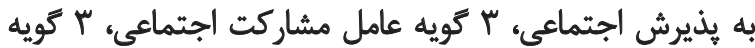
عامل شكوفايى اجتماعى و سرانجام ب كويه مربوط بـ به عارئ عامل انطباق

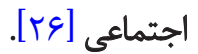

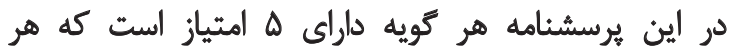

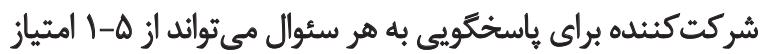

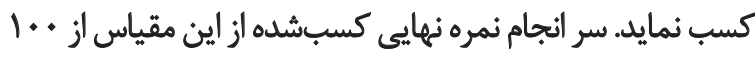

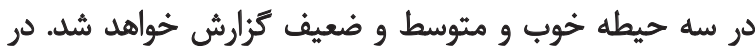

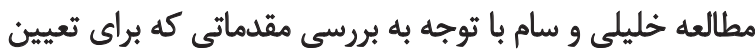

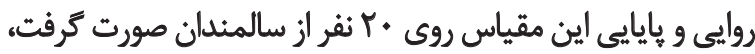




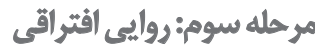

براى سنجش روايى افتراقى آيتمها و همخوانى درونى نسخه

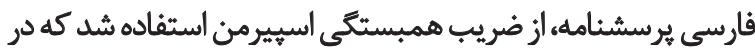

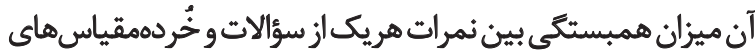
مربوط به آن موردبررسى قرار كرفت

مر حله جهار م: تعيين خردهمقياسهنا

بلمنظور بررسى دقيق اعتبار سازه و تعيين عوامل اين مقياس

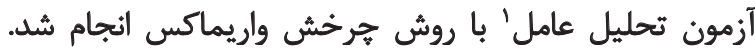

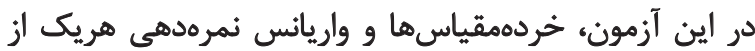

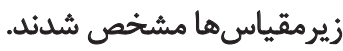

\section{مر حلد ئججم: تعيين باياييى}

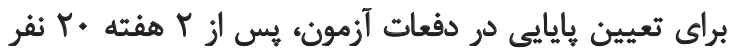

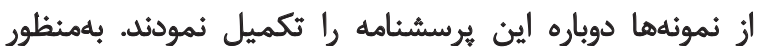

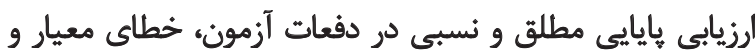

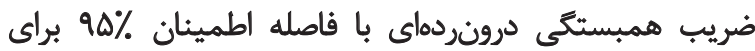

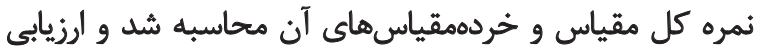

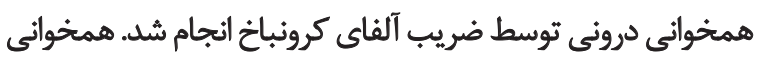

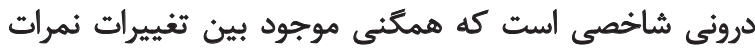

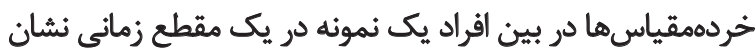

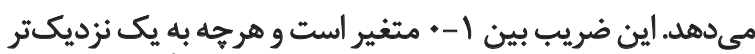

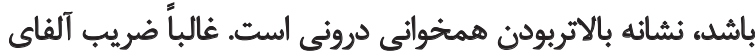

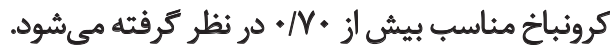

\section{مر حله ششهم: اتجام كار ميدانى}

در اين مرحله، يرسشنامه به بو 19 سالمند ارائه شد. اين مرحله براي

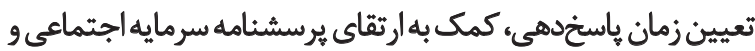

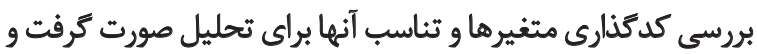

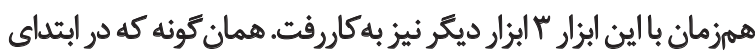

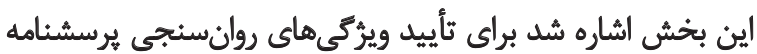

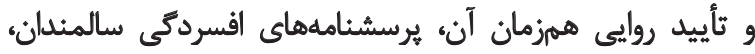

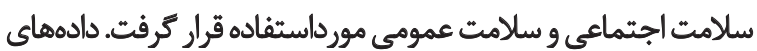

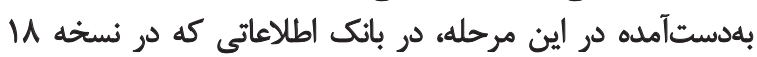

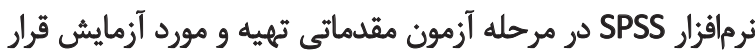

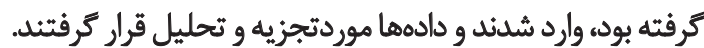

برايى تحليل دادهها از موارد ذيل استفاده شد: تحليل هاى توصيفى

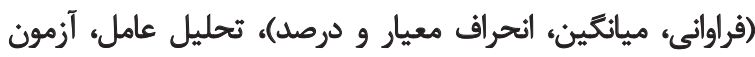

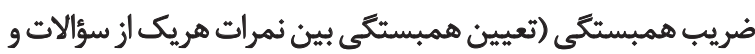

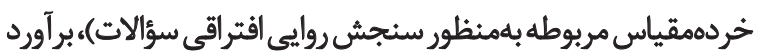

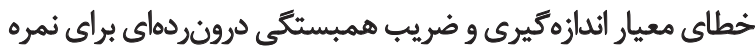

1. Factor analysis r Y- سنجش كيفيت ترجمه: در مرحله بعد بلمنظور سنجش

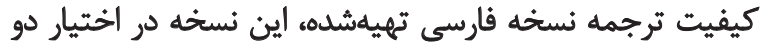

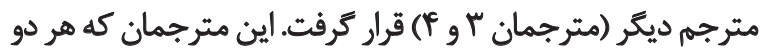

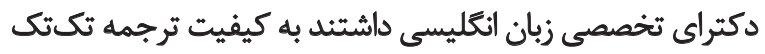

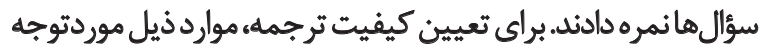

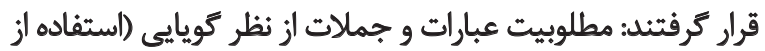

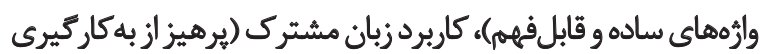

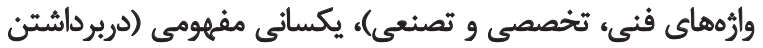

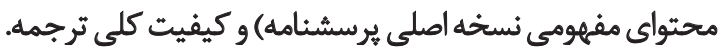
براى سنجش ديدكاه آنان از يك مقياس ديدارى •. 1 نقطهاى

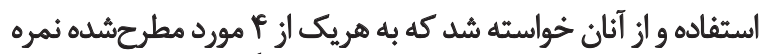

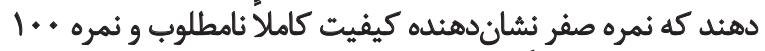

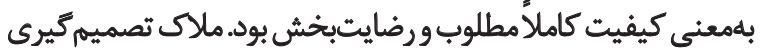

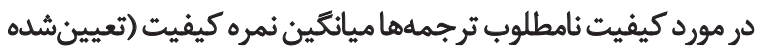

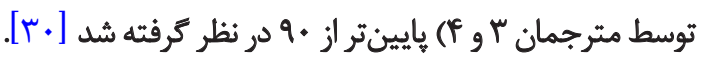

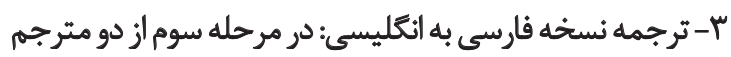

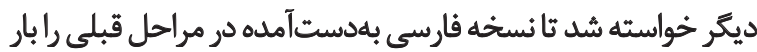

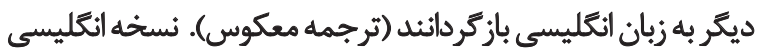

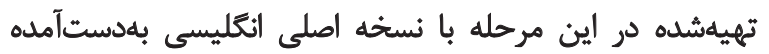

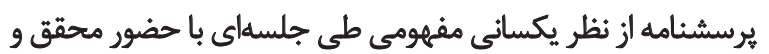

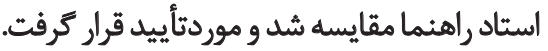
مرحله دوم: بروبيى روايي ظاهرى

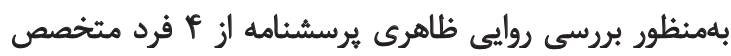

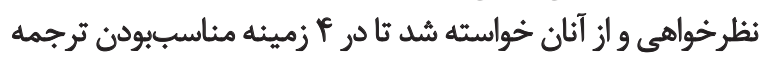

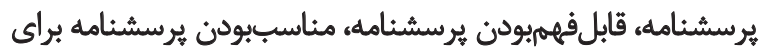

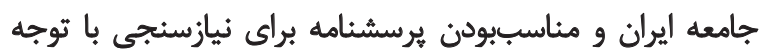

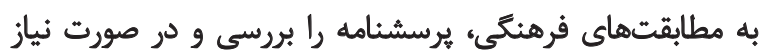

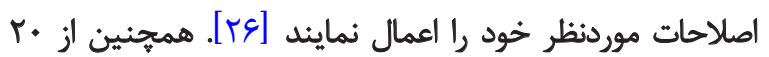

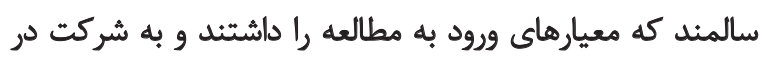

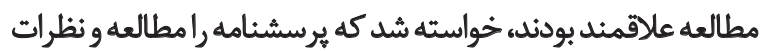

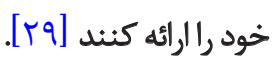
براى اطمينان از ارزشمئدى نظرات سالمندان، افرادى انتخاب

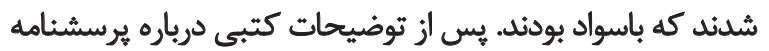

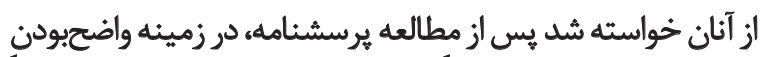

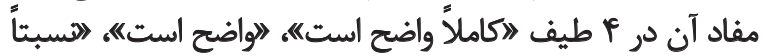

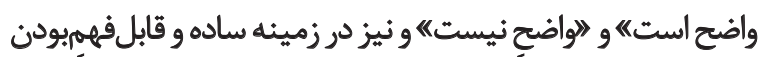

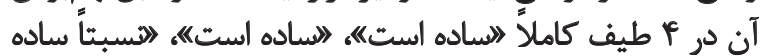

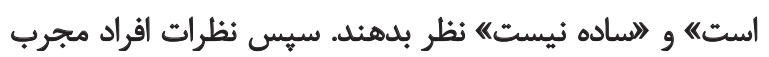

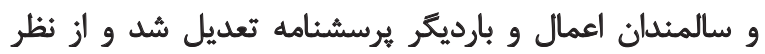

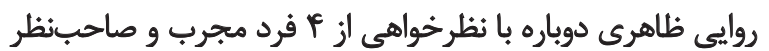

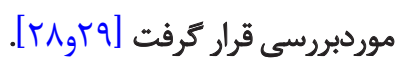


تجزيه و تحليل دادههاى آمارى در زمينه تهيه نسخه فارسى

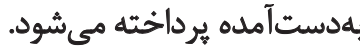

هدف (: بروسى دشوارى ترجمه نسخّله فارسى برسشناهل سرمايه اجتماعى اونيكس

همان كونه كه در بخش روشها عنوان شد، تثاوت نمرات دشوارى

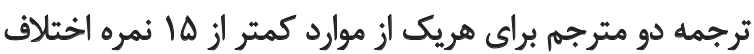

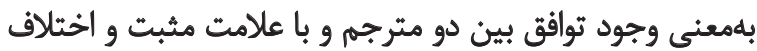
نمرات بيش از ها نمره با علامت منفى بلمعنى عدمتوافق منظور
كل مقياس و خردهمقياس هاى آن (بهمنظور ارزيابى باياييى مطلق و

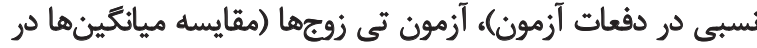

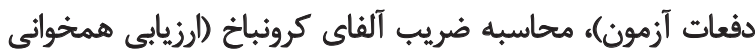

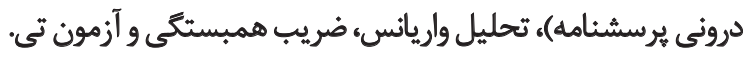

يافتهها

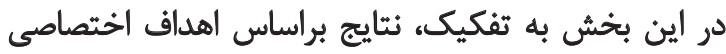

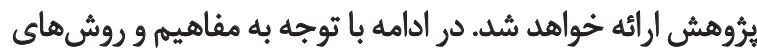

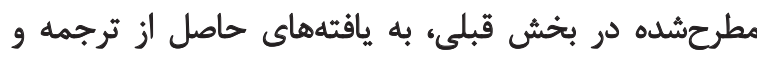

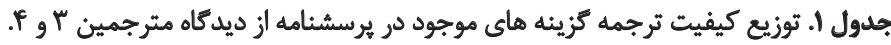

\begin{tabular}{|c|c|c|c|c|c|c|c|c|}
\hline \multicolumn{2}{|c|}{ كيفيت كلي } & \multicolumn{2}{|c|}{ يكسائى مفاهيم } & \multicolumn{2}{|c|}{ كاريردزيان مشئن } & \multicolumn{2}{|c|}{ وضوح ترجمه } & \multirow{2}{*}{ 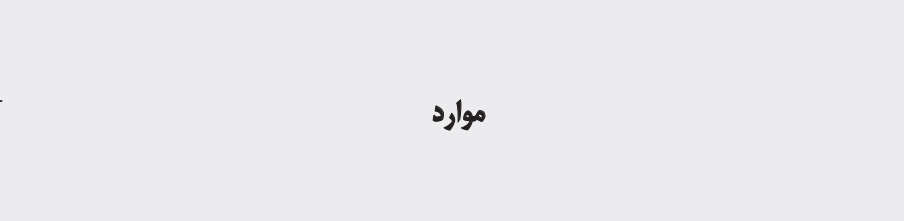 } \\
\hline कू & 3 & $\frac{2}{9}$ & 3 & $\frac{32}{9}$ & $\frac{3}{3.3}$ & $\frac{2}{29}$ & $3_{3}^{3}$ & \\
\hline+ & $1 .+$ & + & $1 .$. & + & $1+$. & + & $1+*$ & در سؤالات زير لطفا بهترين باسخ را علامت بزنيد \\
\hline+ & 9. & + & q. & + & q. & + & $9+$ & آيا جامعه براى شما ارزش ثائل ايت؟ \\
\hline+ & 9. & + & 9. & + & 9. & + & 9. & اكر قرار باشد كه فردا عمر شما تمام شود، آيا از آنجه در زندكى بر شما كذشته راضى هستيد؟ \\
\hline+ & u & + & 9. & + & 9. & + & $1 .$. & آيا تابهمال زبالهاى را كه ديكران در هعاير عمومى ريخته اند جمع كردمايد؟ \\
\hline+ & 1.0 & + & $1 .$. & + & $1 .$. & + & $1 .$. & آيا با اين ايده هوافقيد كه با كمك كردن به ديكران در نهايت به خود كمك كردهايد؟ \\
\hline+ & 90 & + & q. & + & १४ & + & $9 \Delta$ & آيا بهعنوان داوطلب به يك تشكيلات هحلى كمك مى كنيد؟ \\
\hline- & A. & - & A. & + & A. & + & A. & آيا در صورت تاريكى هوا، براى رفتن به خيابان احساس اهنيت مي كنيد؟ \\
\hline+ & 99 & + & Q & + & 4 & + & $1 .$. & آيا با اين ايده مواققيد كه اكثر مردم قابل اعتمادند؟ \\
\hline+ & 10. & + & $1 .+$ & + & 1.0 & + & $1+\infty$ & اكر ماشين كسى در بيرون از خانه شما خراب شود، آيا أز او دعوت مى كنيد كه از ثلفن خانه شما \\
\hline- & q. & + & $\Lambda$. & + & A. & + & 9. & وقتى با مشكلى مواجه شديد آيا مي توائيد از دوستائتان كمك بكيريد؟ \\
\hline+ & $9 \Delta$ & + & $9 \Delta$ & + & $9 \Delta$ & + & $9 \Delta$ & آيا محله شما به يك محله امن معروف است؟ \\
\hline+ & $1 .$. & + & $1 .$. & + & $1 .$. & + & $1 .$. & 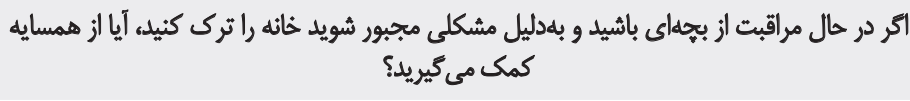 \\
\hline+ & 90 & + & 90 & + & 90 & + & 90 & آيا در طول هفته كذنشته به ديدار يكى از همسايكان خود رفتهايد؟ \\
\hline+ & $1 .+$ & + & $1 .+$ & + & 1.0 & + & $1+$. & آيا در طول \& ماه كذنشته در يكى ازٔ مراسم محله خود شروع به فعاليت كردايد (ماند رفتن به و...) \\
\hline+ & A. & + & A. & + & A. & + & $A \Delta$ & آيا عضو فعال يك تشكيلات يا سازمان محلى هستيد (مثلاً بانشاههاى ورزشى، صنايع دستى، \\
\hline+ & 9. & + & 9. & + & 9. & + & q. & آيا محله خود را مثل خائه خُود مي دائيد؟ \\
\hline+ & q. & + & 9. & + & 9. & + & 9. & 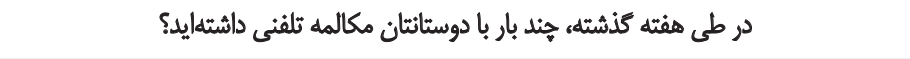 \\
\hline+ & $1 \ldots$ & + & $1 \ldots$ & + & $1 .$. & + & $1 .$. & ديروز با جند ثقر صحبت كردهايد؟ \\
\hline
\end{tabular}




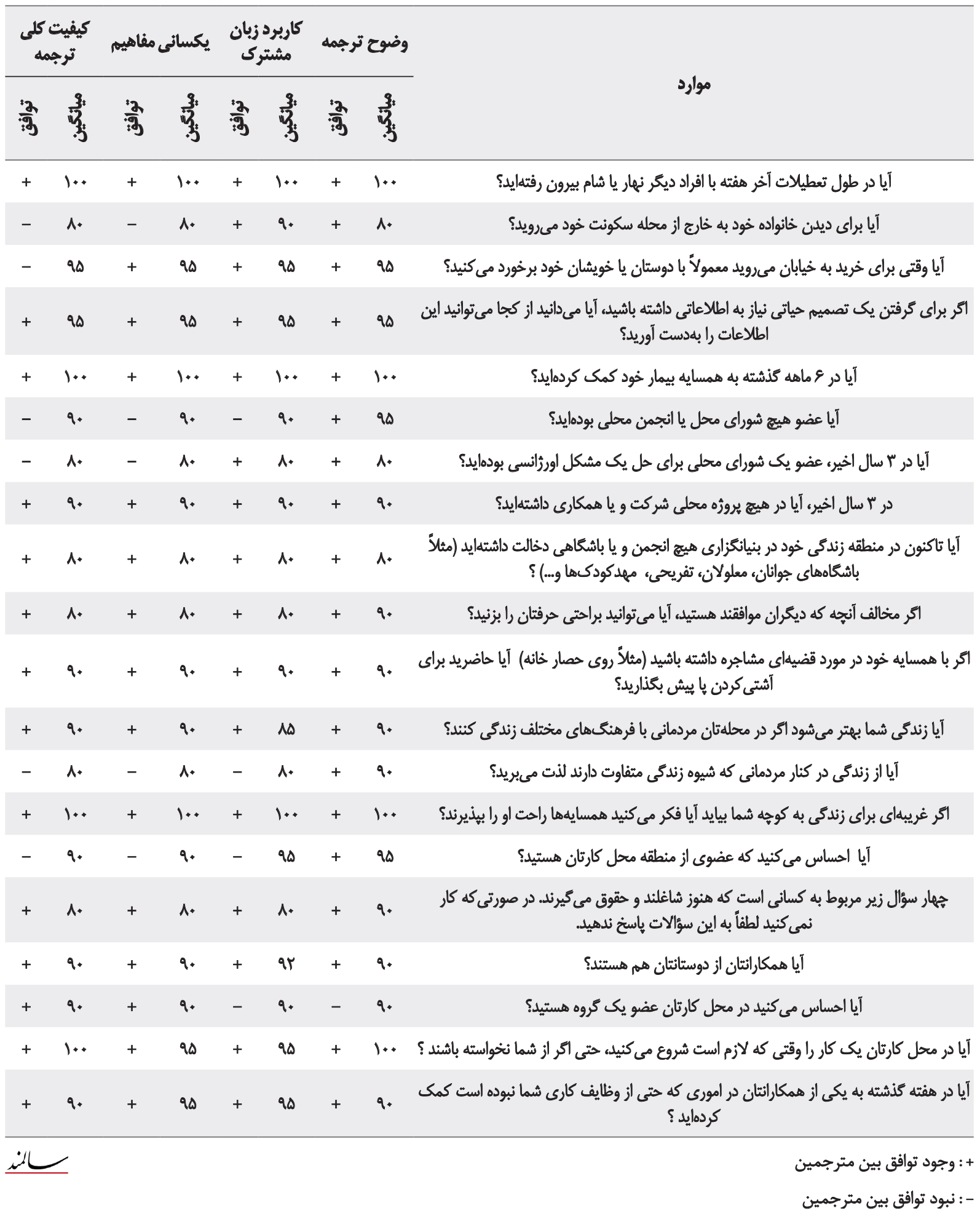

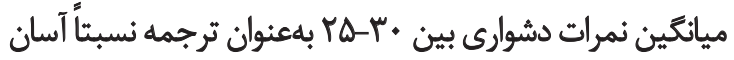

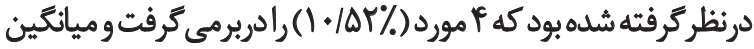

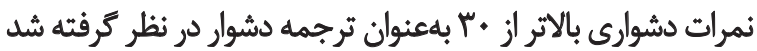

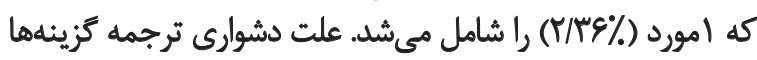

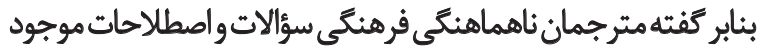

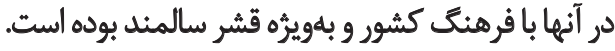

شد. نتايج نشان داد كه بين مترجمان در ^ مورد از كل موارد، در اين زمينه توافق وجود نداشت. در بيشتر كزينهان (VN9\%

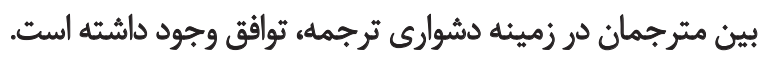

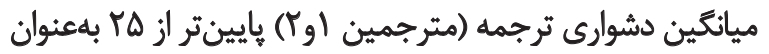

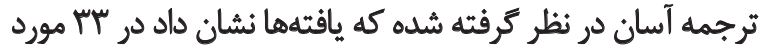
(A $1 / \Lambda \Delta \%)$ 


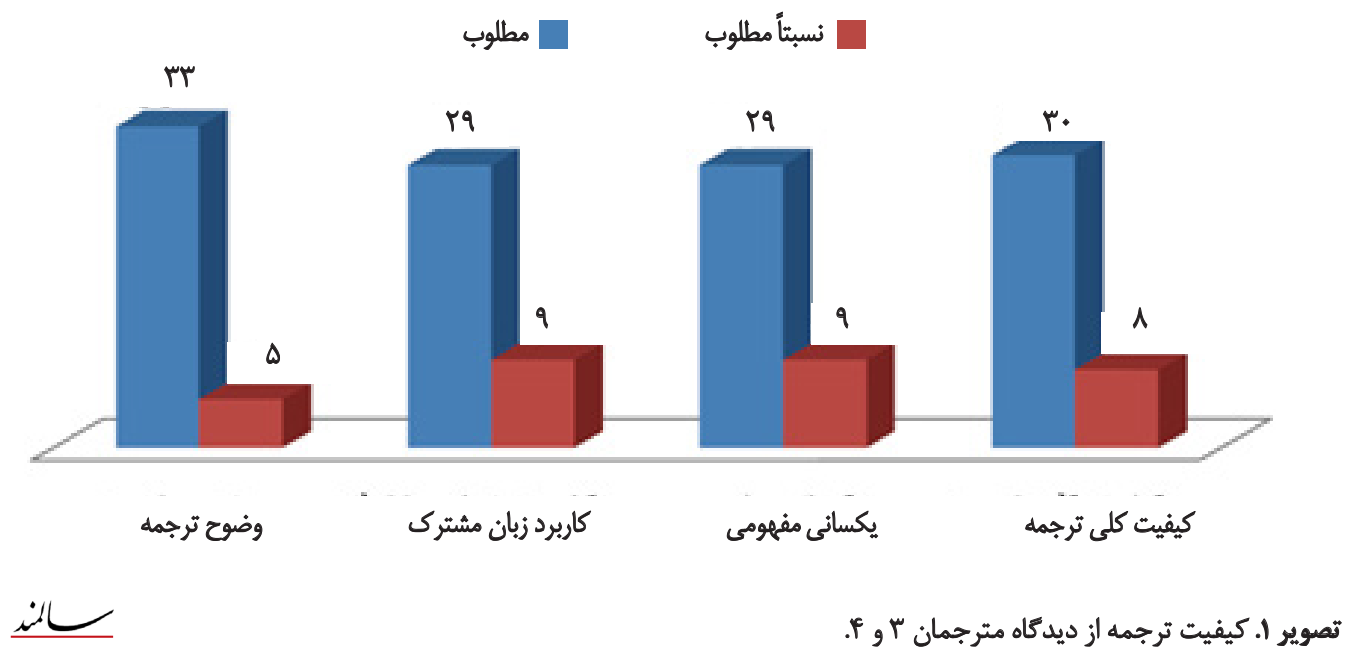

تبادل نظر قرار كرفتند و در صورت لزوم اصلاح شدند. بهاعنوان مثال

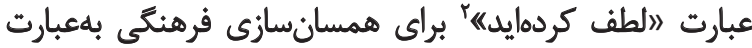

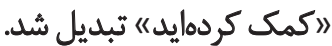

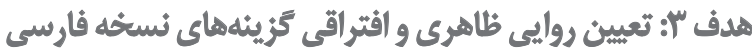
سرمايه اجتماعى اوئيكس همانطوركه در روش كار بيان شده بررسى روايى ظاهرى

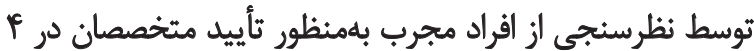

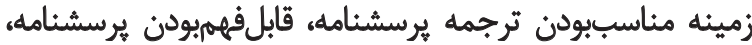

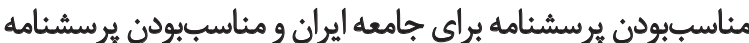

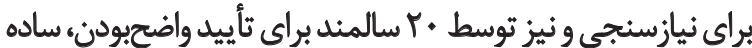

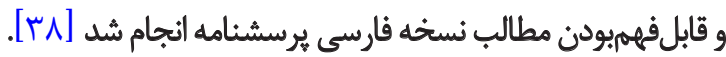
نتايج نشان داد از نظر متخصصان در حوزه مناسبودن ترجمه

2. Done a favour
هدف ץ: تعيين كيفيت ترجما نسخه فارسى برسشنامه سرمايه اجتماعى الوئيكس

يافتهها در زمينه كيفيت ترجمه (وضوح ترجماه، زبان مشترك،

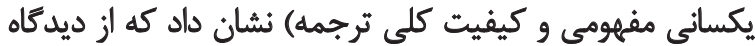

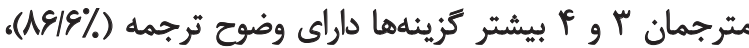

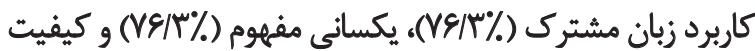
كلى ترجمه (VN9\%) در حد مطلوب بودمانداند (تصوير شماره ()).

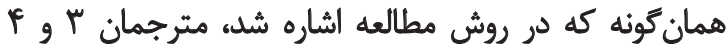

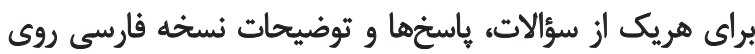

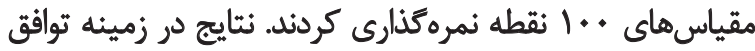

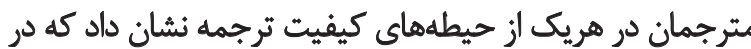

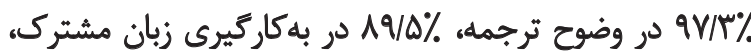

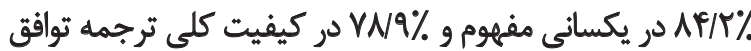

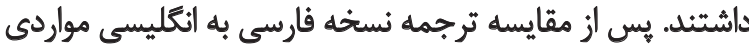

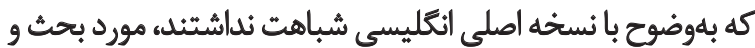

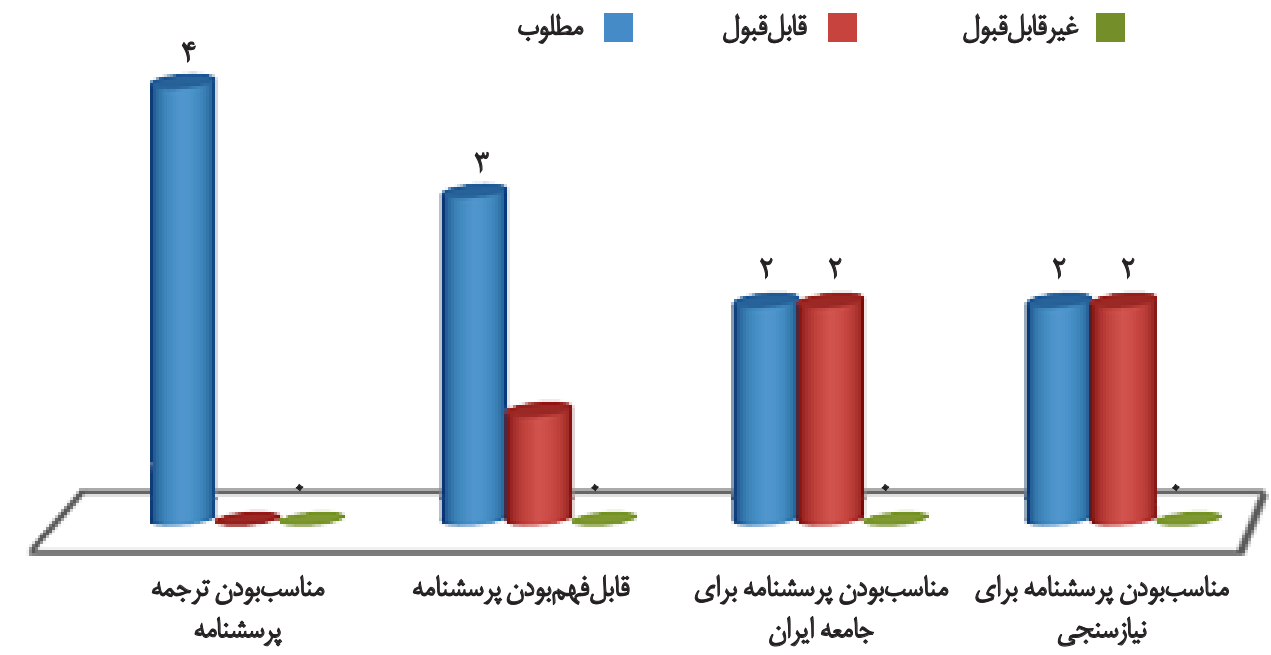


همسايهها راحت او را بيذّيرند؟) محققان اين سؤالات را در دران

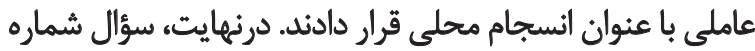

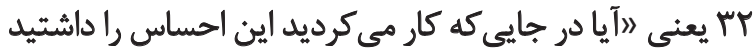

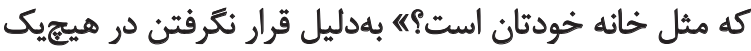

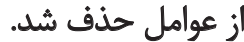

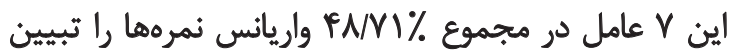

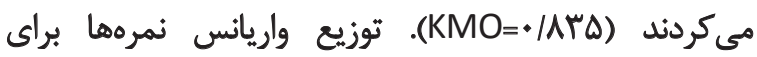

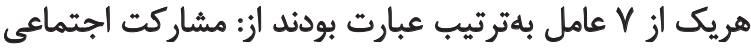
(1/DA\%)

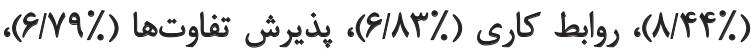

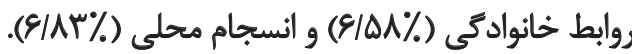

\section{هدف f: تعيين خردهمقياس هاى سرمايه اجتماعى اونيكس}

براى ارزيابى همبستّكى بين نمره هريك از سؤالات در هر

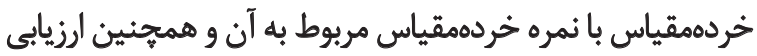

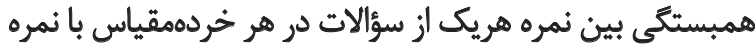

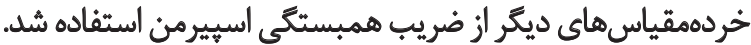

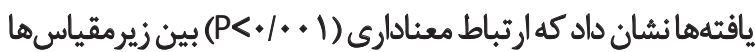

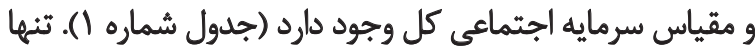

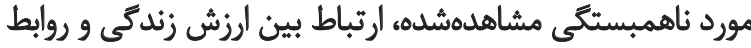

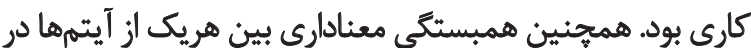

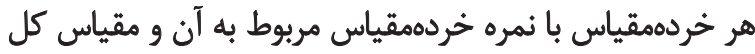

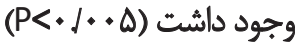

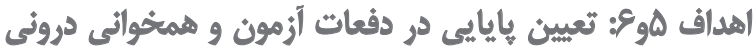
نمرات نسخه فارسى يرسشئامه سر مايه اجتماعى اونيكس فونس يس از دو هفتها آزمون مجدد بلهمنظور تعيين باياييى در دفعات

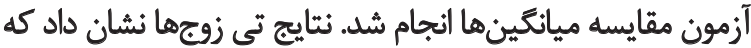

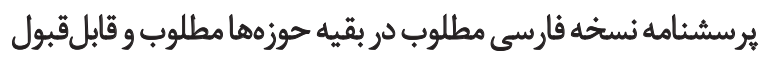

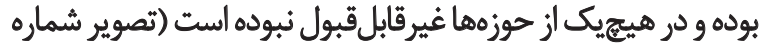

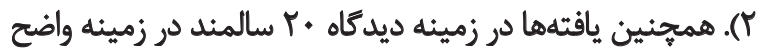

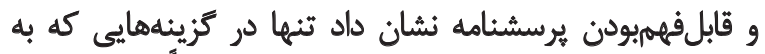

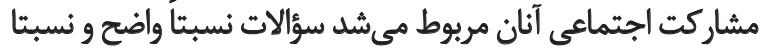

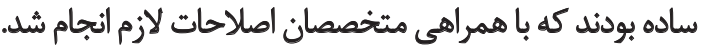
بامنظور سنجش روايى افتراقى آيتمها و همخوانى درونى نسخه

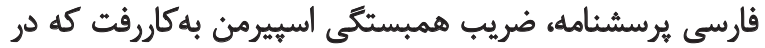

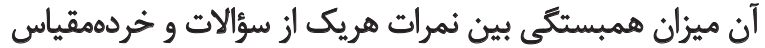

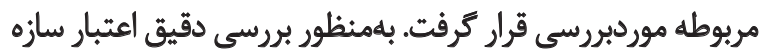

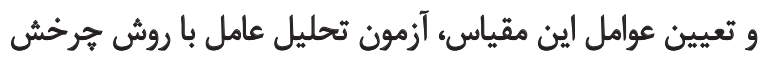

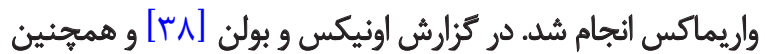

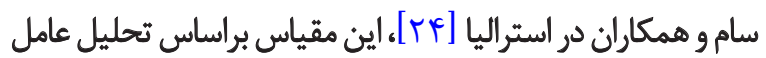

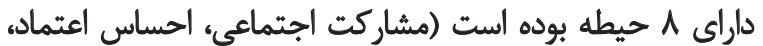

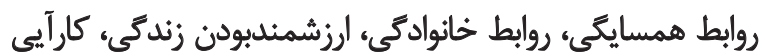
اجتماعى، يذيرش تفاوتهاو روابط كاري).

در تحليل عاملى كه در اين مطالعه روى سالمندان ايرانى انجام

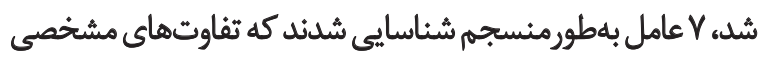

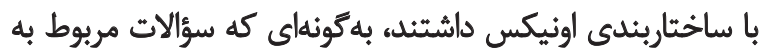

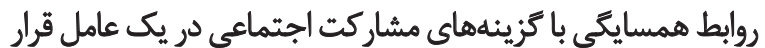

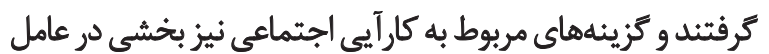

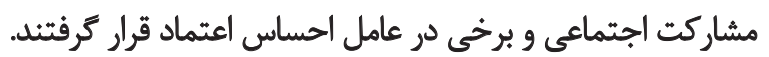

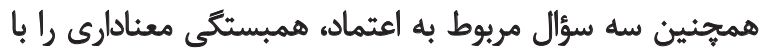
يكديكر در يك عامل مجزا نشان دادئد.

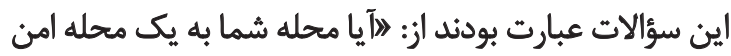

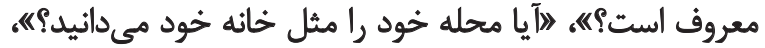
إكر غريبهاي براي زندكى به كوجه شما بيايد آيا فكر مى كنيد

جدول Y. همبستّى بين زيرمقياس هاى سرمايه اجتماعى و سرمايه اجتماعى كل.

هاركت اجتماعى زيرمقياسها




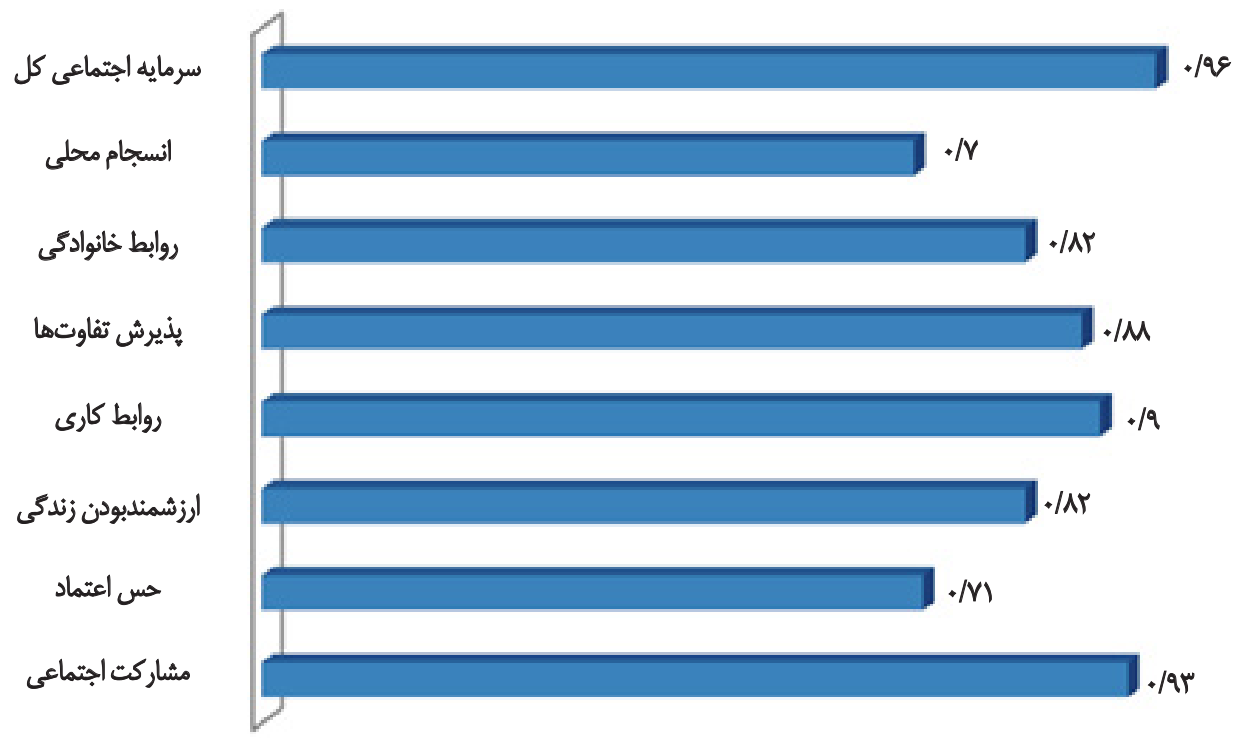

L

افسردكى براى ثأييد آزمون سرمايهاجتماعى بهار إر برده شد. يافتهها

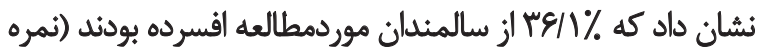

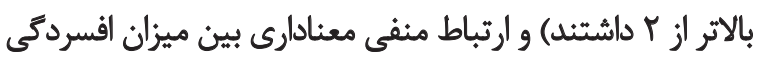

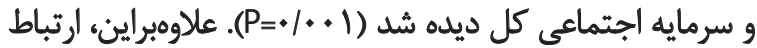

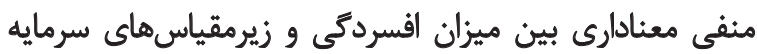

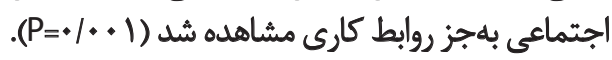

يرسشنامه تعيين سلامت اجتماعى از ديكر ابزارهايى بود كه

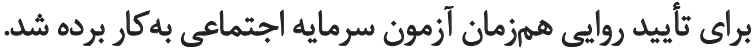

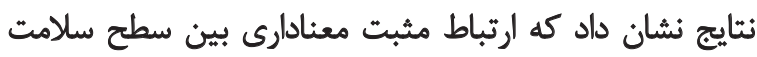

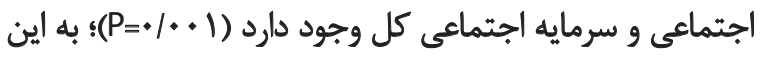

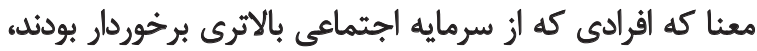
سلامث اجتماعى بالاترى داشتند.

يرسشنامه فرم كوتاه كيفيت زندگى كه وضعيت سلامت عمومى دري

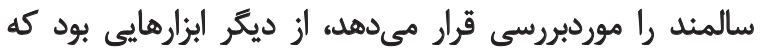

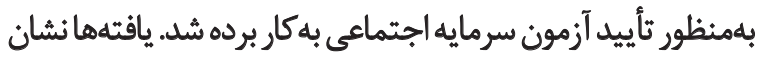

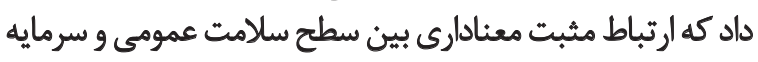

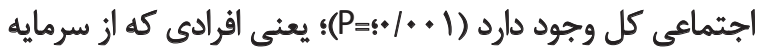
اجتماعى بالاترى برخوردار بودند، سلامت عمومى بالاترى داشتيند.

بحث

تاكنون معيارهاى مختلفى براى تعيين سرمايه اجتماعى جرائ

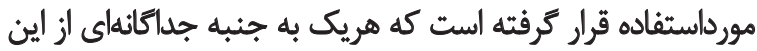

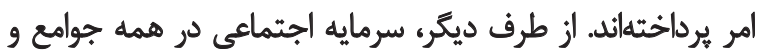

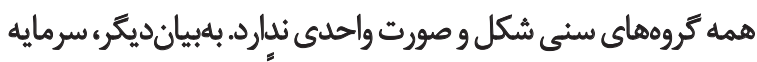

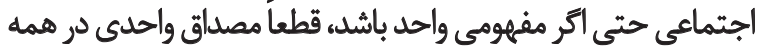

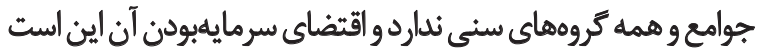

تصوير "ّ. توزيع هايايى آيتمهاى سرمايه اجتماعى كل و زيرمقياسهاى آن.

تفاوت معنادارى بين ميانكين سرمايه اجتماعى در دو دوره وجود

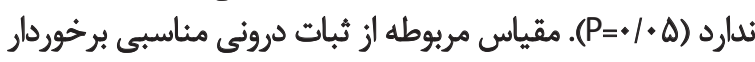

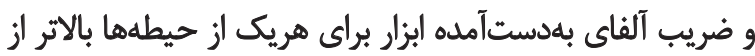

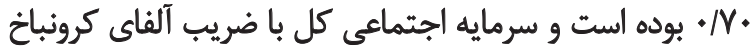
199. بالاترين ميزان هايايى را داشته است (تصوير شماره ب). هدف V: تعيين روايي همرزمان برسششنامه سرمايه اجتماعى

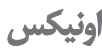
براي تعيين روايى همزمان مقياس، همان تونه كه در مبحث روشها

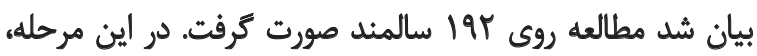

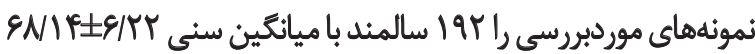

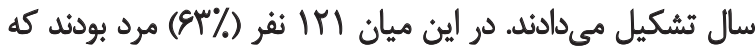

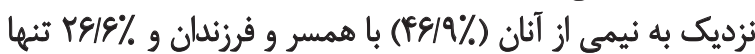

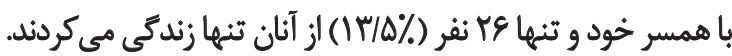

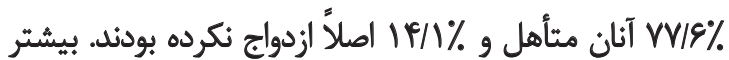

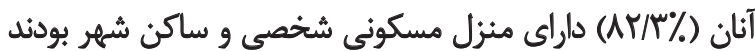

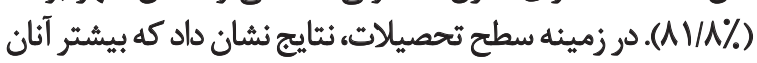

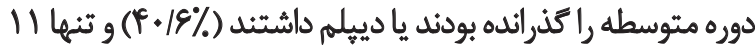

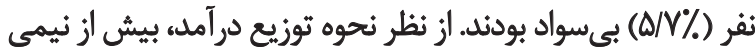

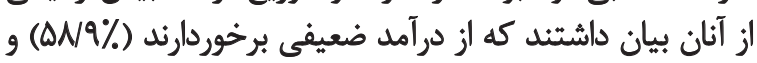

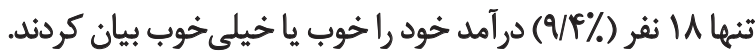

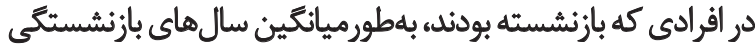

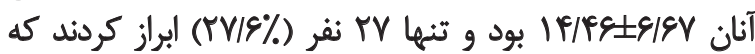

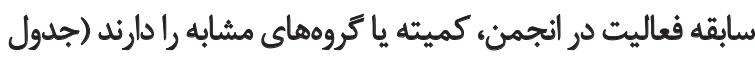

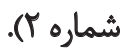

همان كونه كه در روششناسى مطالعه حاضر مطرح شده آزمون 


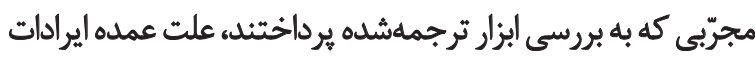

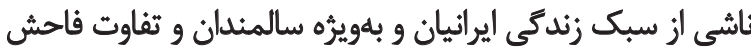

$$
\text { آن با كشورهاى غربى است است ائيان }
$$

در اين يروهش روايى ظاهرى از جهت وضوح و سادتى و وإنى

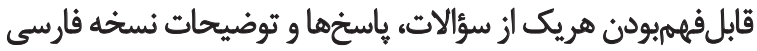

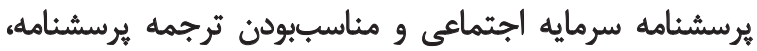

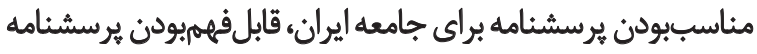

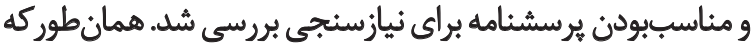

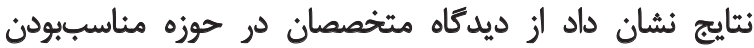

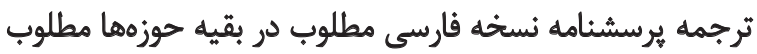

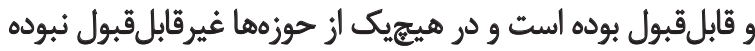

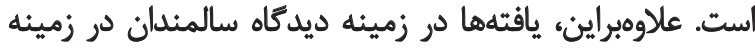

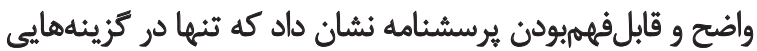

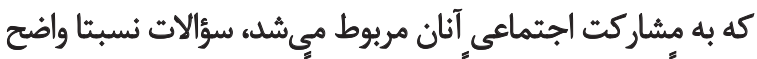

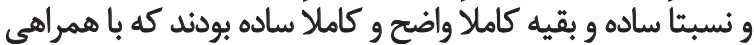
متخصصان اصلاحات لازم انجام شد.

تعيينكئندانرين مسئله در ساختن آزمون "روايىي آن است،

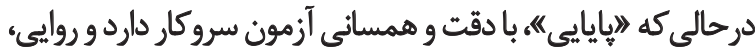

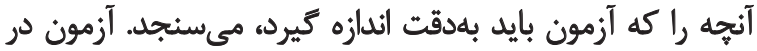

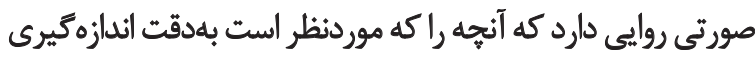

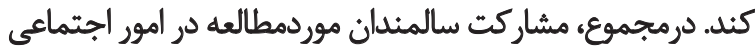

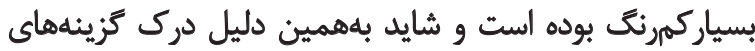

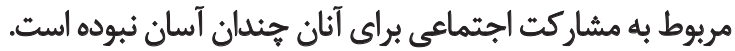

نتايج نشان داد كه درصد كمى از سالمندان بيان نمودند كه در دري

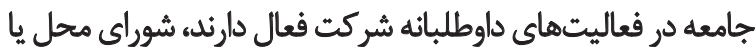

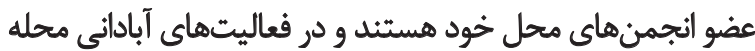

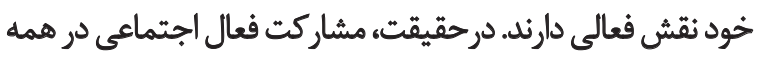

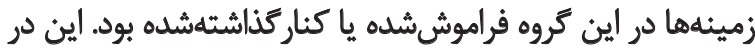

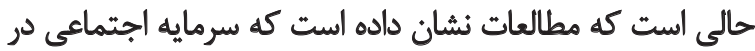

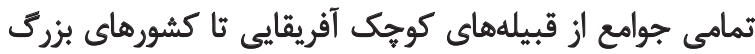

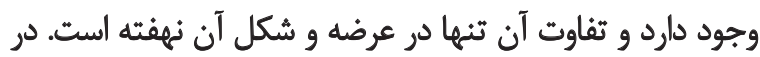

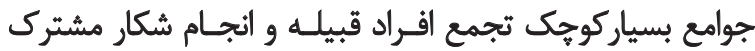

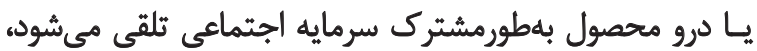

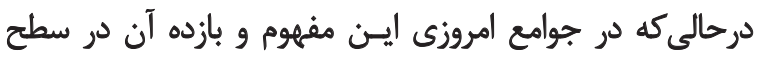

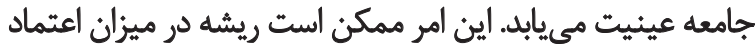

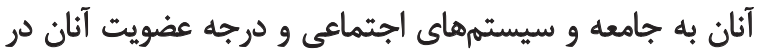

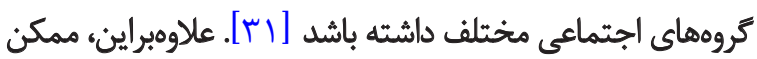
است مربوط به فرهئك ما ايرانيان باشد.

ايرانيان و بهويره سالمندان بلميزان بسياركمترى در جامعانه

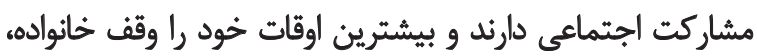

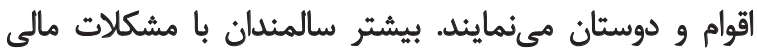

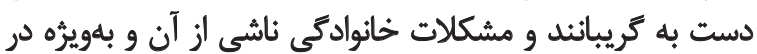

كه در هر جامعالى متناسب با مقتضيات آن جامعه شكل مى كيرد.

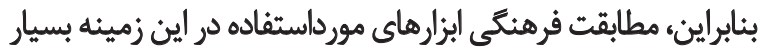

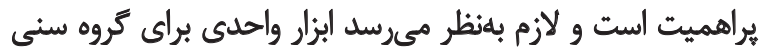

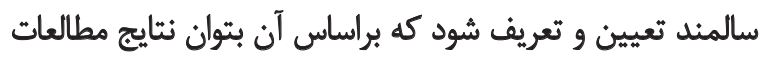

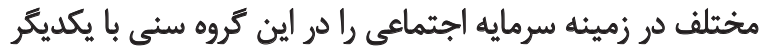

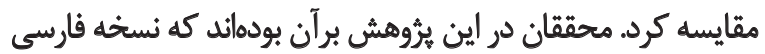

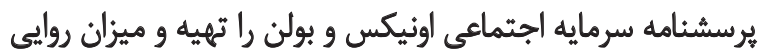

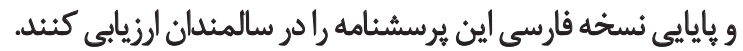

يكى از مهمترين مسائلى كه در مطالعه و بررسى وضعيت

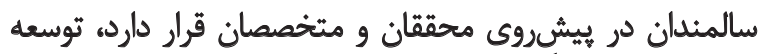

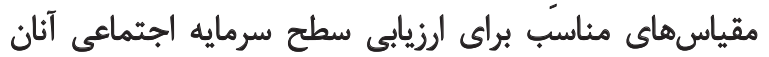

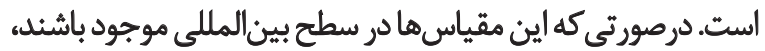

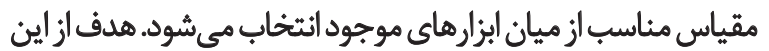

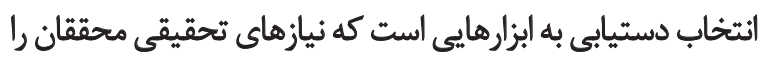

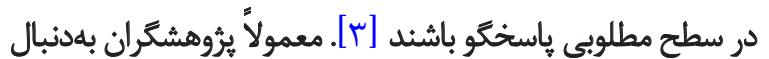

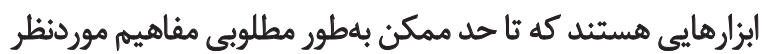

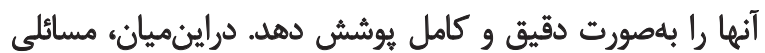

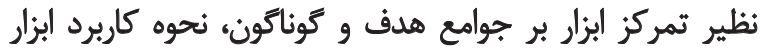

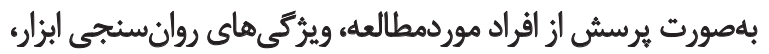

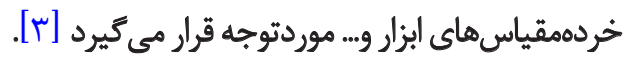
يكى از اصولىترين مواردى كه در انتخاب يك ابزار همواره بايد

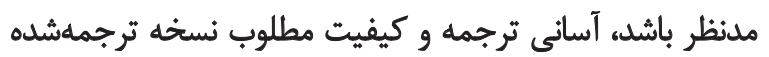

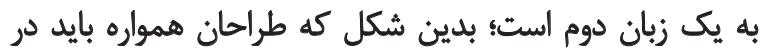

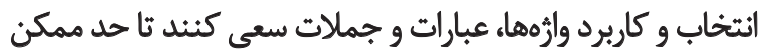

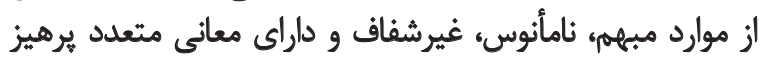

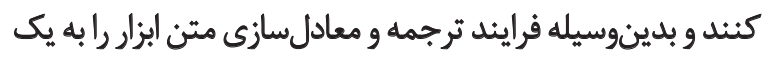

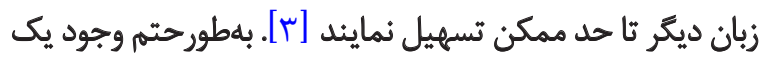

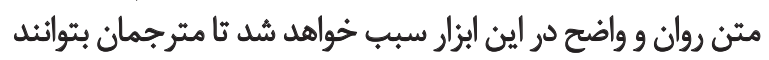

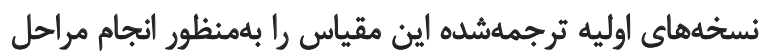
بعدى تحقيقات خود تهيه كنيد.

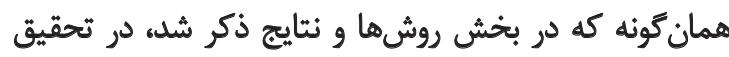

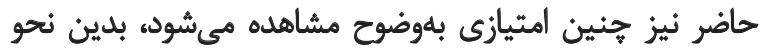

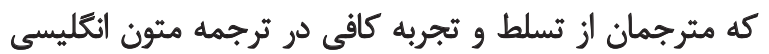

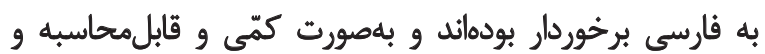

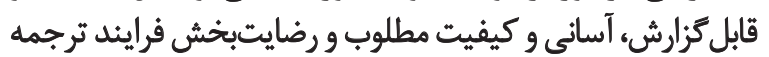

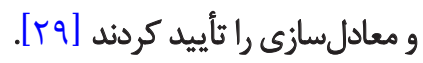
ونتايج نشان داد كه درمجموع، از نظر دشوارى f أمورد نسبتاً دشوار

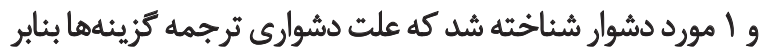

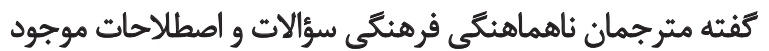

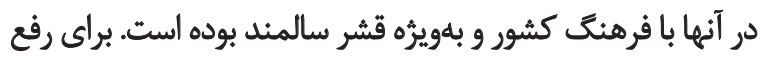

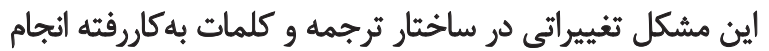

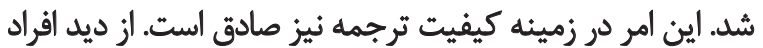


اصلى آن بالاتر بوده است كه از نكات مثبت آن بهاشمار ميرود.

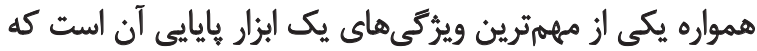

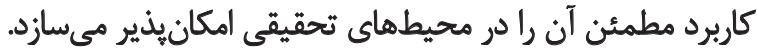

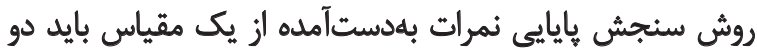

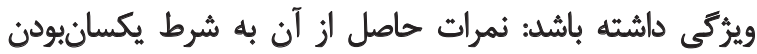

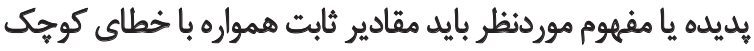

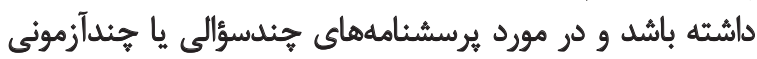

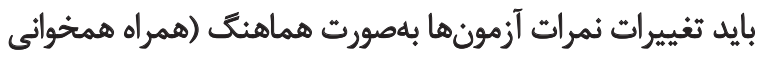

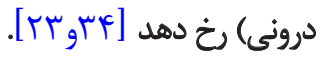

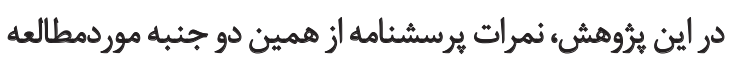

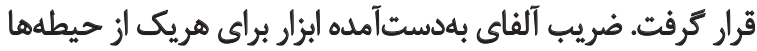

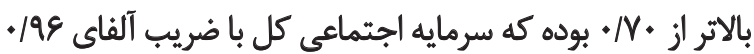

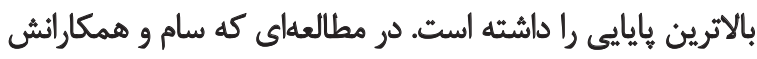

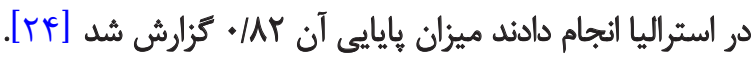

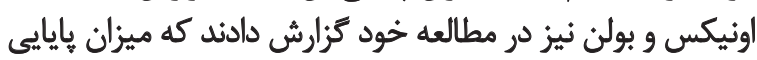

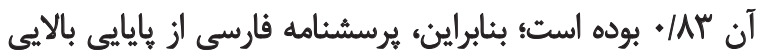
برخوردار بوده است.

همان مونه كه يافتهها نشان داد، ارثباط مثبت معنادادارى بين

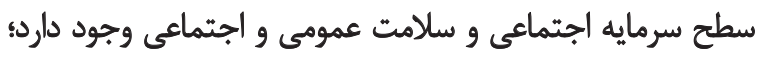

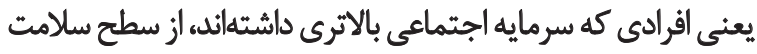

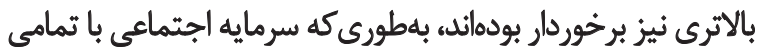

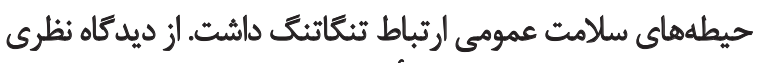

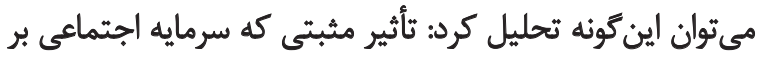

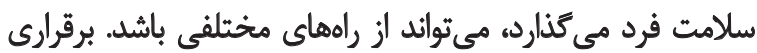

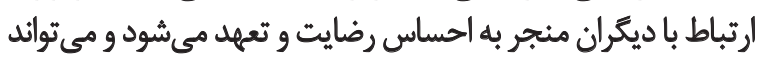

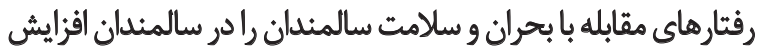

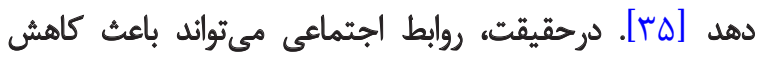

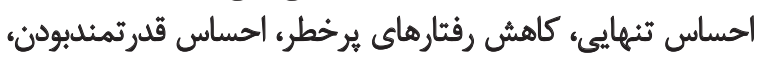

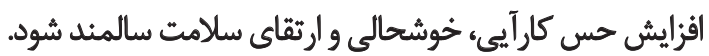

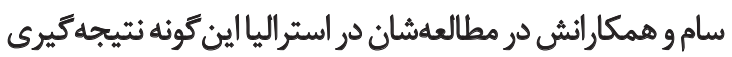

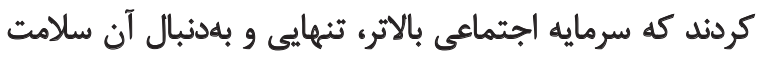

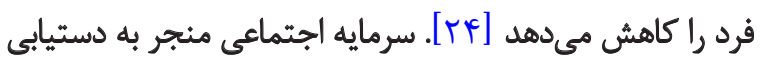

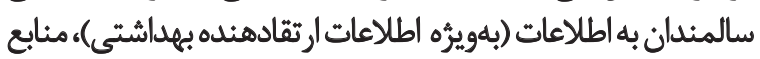

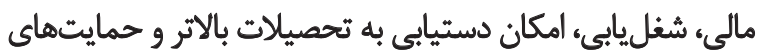

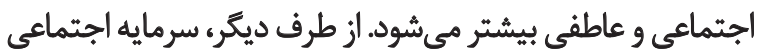

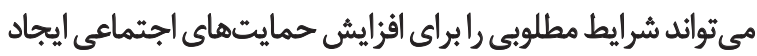

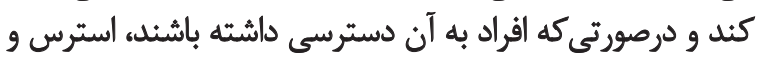

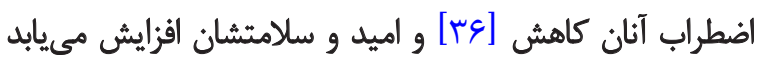

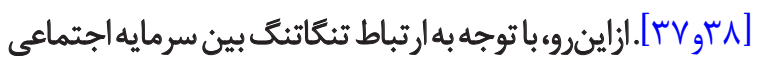

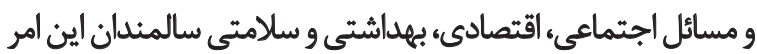

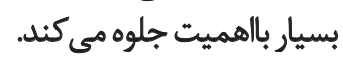

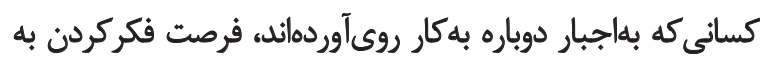

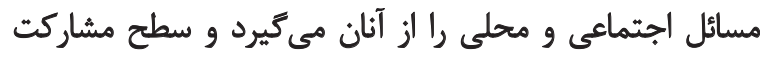

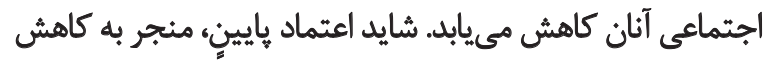

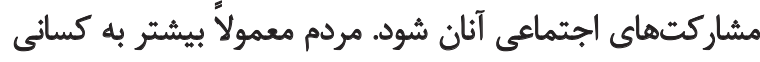

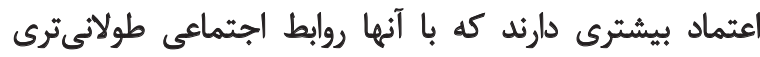

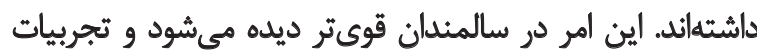

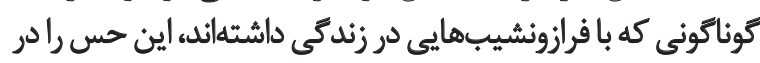

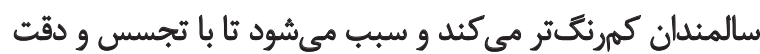

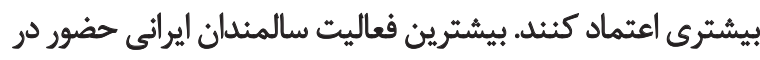

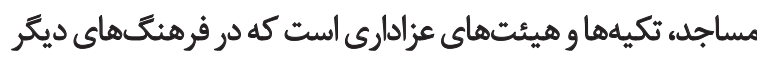

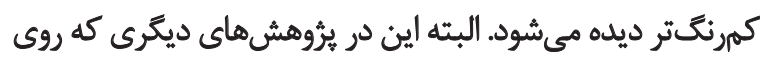

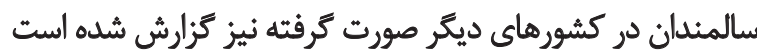

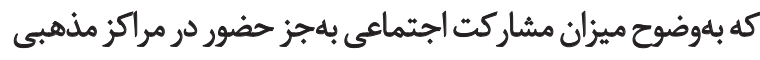

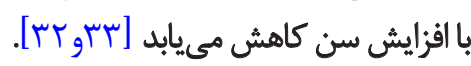

همان طوركه در روش كار مطرح شده، براي سنجش رواييى افتراقي

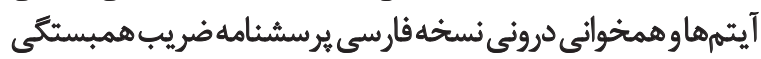

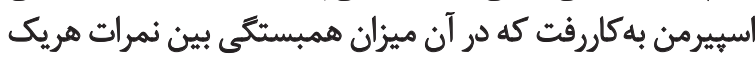

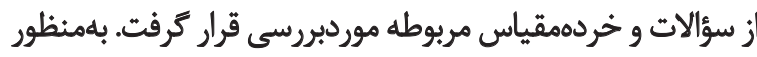

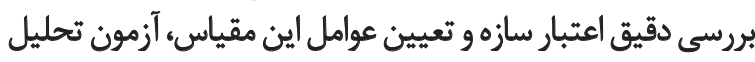

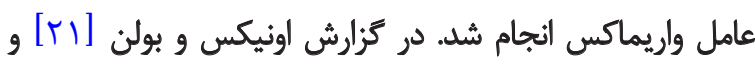

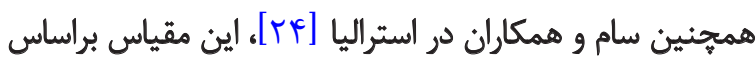

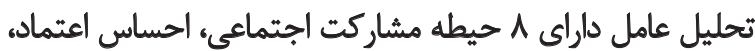

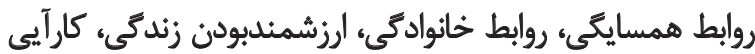
اجتماعى، يذيرش تفاوتها و ورابط كارى بوانو بوده است.

در تحليل عاملى كه در اين مطالعه روى سالمندان ايرانى انجام

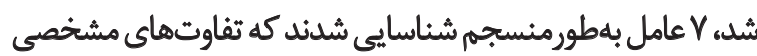

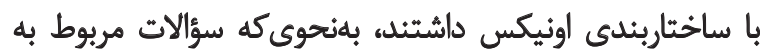

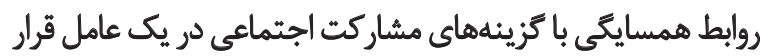

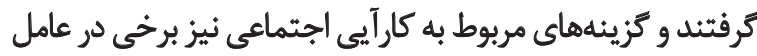

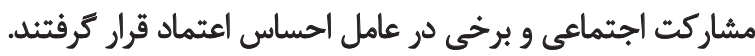

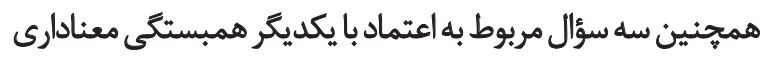

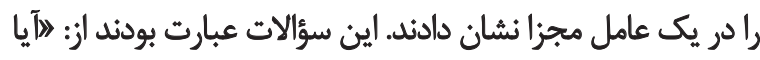

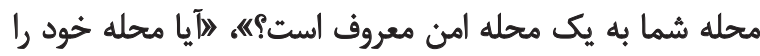

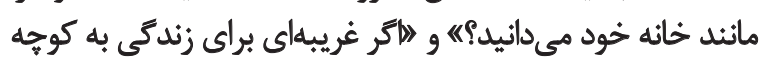

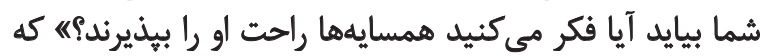

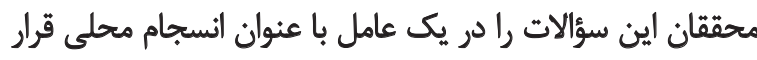

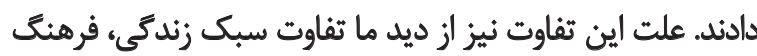

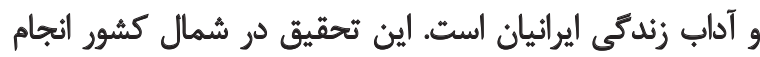

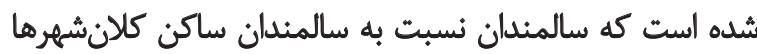

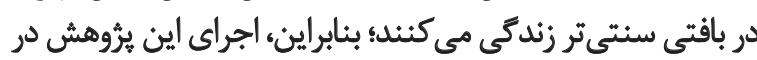
كلانشهرى نظير تهران توصيه مى شئود. خوشبخثائه ميزان بايايى نسخه فارسى اين يرسشنامه از نسخه 


\section{References}

[1] Mellor D, Firth L, Moore K. Can the internet improve the wellbeing of the elderly? Ageing International. 2008; 31(1):25-42.

[2] Victor CR, Scambler SJ, Bowling AN, Bond J. The prevalence of, and risk factors for, loneliness in later life: A survey of older people in Great Britain. Ageing and Society. 2005; 25(6):357-75.

[3] Mulvaney-Day NE, Alegria M, Sribney W. Social cohesion, social support, and health among Latinos in the United States. Social Science \& Medicine. 2007; 64(2):477-95.

[4] Hall M, Havens B. The effect of social isolation and loneliness on the health of older women [Internet]. Prairie Women's Health Center of Excellence; 2001. Available from: http:/ /www.pwhce. $\mathrm{ca} / \mathrm{effectSociallsolation.htm.}$

[5] Bishop HB. The national strategy for an ageing Australia: Attitude, lifestyle \& community support. Canberra ACT: Commonwealth of Australia; 2000.

[6] Norstrand JA, Xu Q. Social capital and health outcomes among older adults in China: The urban-rural dimension. Gerontologist. 2012; 52(3):325-34.

[7] Engström KF, Mattsson A, Järleborg JH. Contextual social capital as a risk Factor for poor self-rated health: A multilevel analysis. Social Science and Medicine. 2008; 66(11):2268-80.

[8] Snelgrove JW, Pikhart H, Stafford M. A multilevel analysis of social capital and self-rated health: Evidence from the British Household Panel survey. Social Science \& Medicine. 2009; 68(11):1993-2001.

[9] Rowe JW, Kahn R. Successful ageing. Gerontologist. 1997; 37(4):433-40.

[10] William A. Epidemiology of ageing: An ecological approach. California: Amazon Press; 2005.

[11] Putnam RD. Bowling alone: The collapse and revival of American community. New York: Simon \& Schuster; 2000.

[12] Viswanath K, W, Randolph S, Finnegan JR. Social capital and health: Civic engagement, community size, and recall of health messages. American Journal of Public Health. 2006; 96(8):1456-61.

[13] Kawachi I, Berkman L. Social cohesion, social capital and health. In: Berkman LF, Kawachi I, editors. Social Epidemiology. New York: Oxford University Press; 2000, pp. 174-90.

[14] Coleman JS. Foundations of social theory. Cambridge: Harvard University Press; 1990.

[15] Bankston CL, Zhou M. Social capital as process: The meanings and problems of a theoretical metaphor. Sociological Inquiry. 2002; 72(2):285-317.

[16] Granovetter MS. Strength of weak ties. American Journal of Sociology. 1973; 78(6):1360-80.

[17] Fukuyama F. Social capital and development. Coming Agenda SAIS Review. 2002; 22(1):23-37.

[18] Falk I, KilpatrickS. What is social capital? A study of interaction in a rural community. Sociologia Ruralis. 2000; 40(1):87-110.

[19] Stone W. Measuring social capital: Towards a theoretically informed measurement framework for researching social capital in family and community life [Research Paper]. Melborne: Australian Institute of Family Studies; 2001.

\section{نتيجه تيرى نهايی}

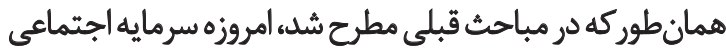

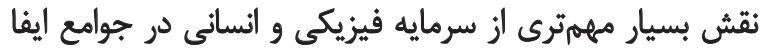

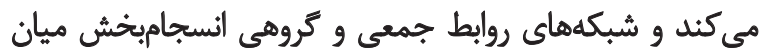

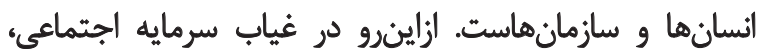

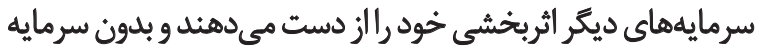

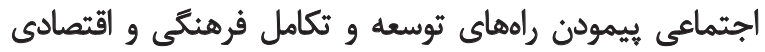

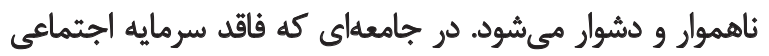

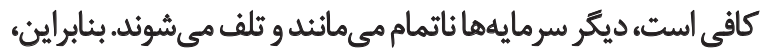

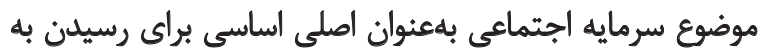

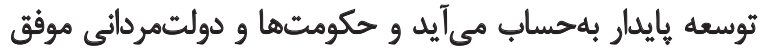

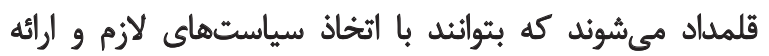

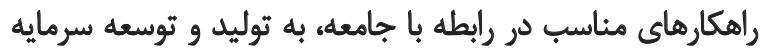

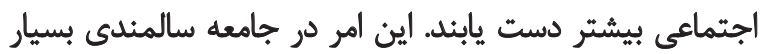

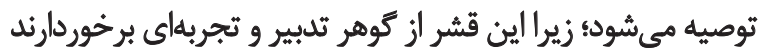
كه بهراحتى نبايد از آن كذشت آنش

اجراى اين مطالعه با محدوديتهايى همراه بوده كه مهرمترين براني

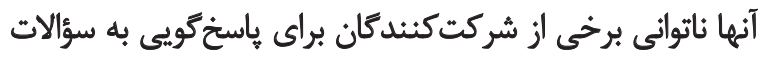

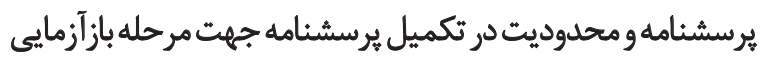

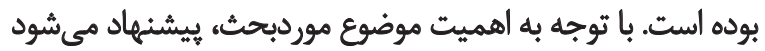

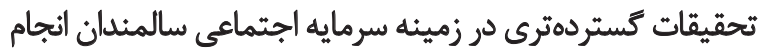

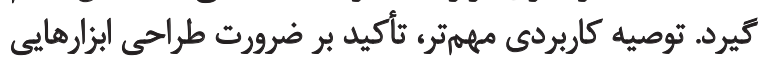

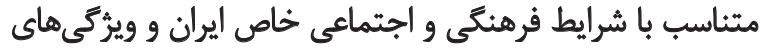
سايكومتريك قابلقبول و كارآيى مناسب براى سنجش إن سرمايه

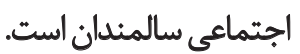


[20] Beugelsdijk S, Smulders S. Bridging and bonding social capital: Which type is good for economic growth? [Internet]. 2004; Available from: http://www-sre.wu-wien.ac.at/ersa/ersaconfs/ ersa03/cdrom/papers/517.pdf.

[21] Onyx J, Bullen P. Measuring social capital in five communities. Journal of Applied Behavioral Science. 2000; 36(1):23-42.

[22] Nobakht Z, Rassafiani M, Rezasoltani P. Validity and reliability of Persian version of Craig Hospital Inventory of Environmental Factors (CHIEF) in children with cerebral palsy. Iranian Rehabilitation Journal. 2011;1(9):13

[23] Khosrofar F. [Evaluation of validity and reliability of Iranian questionnare in people with lower limb amputation (Persian)]. Teharn: University of rehabilitaion and Social welfare; 2011.

[24] Sum S, Mathews M, Pourghasem M, Hughes I. Internet technology and social capital: How the internet affects seniors' social capital and wellbeing. Journal of Computer-Mediated Communication. 2008; 14(1):202-20

[25] Hoyl M, Alessi CA, Harker JO, Josephson KR, Pietruszka FM, Koelfgen $\mathrm{M}$, et al. Development and testing of a five-item version of the Geriatric Depression Scale. Journal of the American Geriatrics Society. 1999; 47(7):873-8

[26] Keyes CLM, Shapiro A. Social well-being in the United States: A descriptive epidemiology. A national study of well-being at midlife. Chicago: University of Chicago Press; 2004.

[27] Khalili F, Sum S, Sharifirad G, Hassanzadeh A, Kazemi M. The relationship between perceived social support and social health of elderly. Journal of Health System Research. 2012; 7(6):1216-25.

[28] Birks Y, Nelson EA, Scanlon E, Cullum NA. Quality of life of people with venous leg ulcers: A comparison of the discriminative and responsive characteristics of two generic and a disease specific instruments. Quality of Life Research. 2005; 14(7):1705-18.

[29] Bullinger M, Alonso J, Apolone G, Leplège A, Sullivan M, Wood-Dauphinee $\mathrm{S}$, et al. Translating health status questionnaires and evaluating their quality: The IQOLA Project approach. International Quality of Life Assessment. Journal of Clinical Epidemiology. 1998; 51(11):913-23.

[30] Drukker M, Kaplan C, Feron F, Van Os J. Children's health-related quality of life, neighbourhood socio-economic deprivation and social capital. A contextual analysis. Social Science \& Medicine. 2003; 57(5):825-41

[31] Ostrom E, Ahn TK. Foundations of social capital. Florida: Florida State University; 2003.

[32] Stoltz E. Do income and education affect civic participation through the components of social capital? In: Basnyat A, Cary A, Chahla E, Johnson B, Jun M, Layman A, et al, editors. The Social State. Minnesota: Department of Political Science Carleton College; 2003. Available from: http://www.acad.carleton.edu/curricular/Posc/Mnsc/Mnscap.pdf.

[33] Milyo J, Parnekar I. Income inequality, social capital and mortality: Re-examining the state-level data. Chicago: University of Chicago; 2003.

[34] Fardinpour S. [Evaluation of validity and reliability of TAPES questionnare in people with lower limb amputation (Persian)]. Tehran: University of Rehabilitaion and Social Welfare; 2011.
[35] Rashedi V, Gharib M \& Yazdani AA. Social participation and mental health among older adults in Iran. Iranian Rehabilitation Journal. 2014; 12(1):9-13

[36] Rashedi V, Gharib M, Rezaei M, Yazdani A. [Social Support and Anxiety in the Elderly of Hamedan, Iran (Persian)]. Journal of Rehabilitation. 2013; 14(2):110-115.

[37] Shakerinia I. [Effect of social assists and hopefulness in elderly health status with chronic pain (Persian)]. Iranian Journal of Ageing. 2012; 7(1):7-15.

[38] Nabavi H, Alipour F, Hejazi A, Rabani Z, Rashedi V. [Relationship between social support and mental health in older adults (Persian)]. Medical Journal of Mashhad University of Medical Sciences. 2014; 57(7):841-846 
